\title{
Recent advances and perspectives in efforts to reduce the production and application cost of microbial flocculants
}

\author{
Cong Liư ${ }^{\dagger}$ Di Sun ${ }^{\dagger}$, Jiawen Liu, Jingrong Zhu and Weijie Liu* (i)
}

\begin{abstract}
Microbial flocculants are macromolecular substances produced by microorganisms. Due to its non-toxic, harmless, and biodegradable advantages, microbial flocculants have been widely used in various industrial fields, such as wastewater treatment, microalgae harvest, activated sludge dewatering, heavy metal ion adsorption, and nanoparticle synthesis, especially in the post-treatment process of fermentation with high safety requirement. However, compared with the traditional inorganic flocculants and organic polymeric flocculants, the high production cost is the main bottleneck that restricts the large-scale production and application of microbial flocculants. To reduce the production cost of microbial flocculant, a series of efforts have been carried out and some exciting research progresses have been achieved. This paper summarized the research advances in the last decade, including the screening of high-yield strains and the construction of genetically engineered strains, search of cheap alternative medium, the extraction and preservation methods, microbial flocculants production as an incidental product of other biological processes, combined use of traditional flocculant and microbial flocculant, and the production of microbial flocculant promoted by inducer. Moreover, this paper prospects the future research directions to further reduce the production cost of microbial flocculants, thereby promoting the industrial production and large-scale application of microbial flocculants.
\end{abstract}

Keywords: Microbial flocculants, Bioflocculant-producing strain, Polysaccharide flocculant, Alternative medium, Application, Extraction

\section{Introduction}

Flocculant is a kind of agent that can reduce or eliminate the colloid stability of dispersed particles in water, and make the dispersed particles coagulate and flocculate into aggregates (Kaarmukhilnilavan et al. 2020; Salehizadeh and Shojaosadati 2001; Salehizadeh et al. 2018). Therefore, flocculants are widely used in various industrial fields, such as wastewater treatment, mining, food processing, and post-treatment of fermentation (Liu et al. 2015d, 2019; Salehizadeh and Yan 2014; Salehizadeh et al. 2018; Shahadat et al. 2017), among which the demand for

\footnotetext{
*Correspondence: leonliu2013@126.com

${ }^{\dagger}$ Cong Liu and Di Sun have contributed equally to this work

Jiangsu Key Laboratory of Phylogenomics \& Comparative Genomics,

School of Life Science, Jiangsu Normal University, No.101, Shanghai road,

Tongshan New District, Xuzhou 221116, Jiangsu, China
}

flocculants is the largest in the field of wastewater treatment. At present, flocculants are mainly divided into inorganic flocculants, organic polymeric flocculants, and bioflocculants (Salehizadeh and Shojaosadati 2001; Salehizadeh and Yan 2014). Among them, inorganic flocculants are mainly represented by aluminum sulfate, poly-aluminum chloride, ferric chloride, and ferrous sulfate (Okaiyeto et al. 2016; Salehizadeh and Yan 2014). However, ferric salt is corrosive, and the accumulation of aluminum salt in human body is directly related to Alzheimer's disease (Campbell 2002). Organic polymeric flocculants are represented by polyacrylamide derivatives and polyethyleneimine (Salehizadeh and Shojaosadati 2001). However, polyacrylamide derivatives are difficult to be degraded, and its degraded monomer acrylamide exhibits a strong biological toxicity (Salehizadeh and Yan 
2014). Therefore, the application of inorganic flocculants and organic polymeric flocculants in industrial fields with high safety requirement is greatly limited (Okaiyeto et al. 2016). Bioflocculant is a class of biological macromolecular substances with flocculating activity obtained from biological sources (Salehizadeh et al. 2018), including plant sources, such as polysaccharides extracted from cactus; animal sources, such as bioflocculant obtained from Ruditapes philippinarum (Mu et al. 2018, 2019); and microbial sources, such as microbial flocculants extracted from fermentation broth of microorganism (Shahadat et al. 2017). Among them, the studies on microbial flocculants are the most concerned.

Microbial flocculants are mainly composed of polysaccharides, proteins produced by microorganisms in the process of fermentation, and nucleic acids released mainly by cell lysis (Liu et al. 2010; Tang et al. 2014a). Compared with inorganic flocculants and organic polymeric flocculants, microbial flocculants have the characteristics of biodegradation, non-toxic and harmless, no secondary pollution (Chaisorn et al. 2016; Liu et al. 2015d). Therefore, microbial flocculants show good safety advantages in food processing and fermentation post-treatment processes (Ndikubwimana et al. 2014). For example, during the production of biodiesel using microalgae cells, the concentration cost of microalgae cells accounts for $30-50 \%$ of the production cost of biodiesel (Liu et al. 2015d; Wan et al. 2013). Flocculation is an effective method to reduce the cost of microalgae harvest (Liu et al. 2015d, 2017a; Roy and Mohanty 2020). However, the safety of flocculants is a key consideration, because in addition to producing biodiesel, microalgae cells can also be used for the extraction of microalgae polysaccharides or the production of animal feeds (Bernaerts et al. 2018; Markou and Nerantzis 2013). Using inorganic flocculants or organic polymeric flocculants to flocculate microalgae has adverse effects on the quality of biodiesel and the production of high value-added products from microalgae cells (Liu et al. 2017a; Wan et al. 2013). Therefore, the research on the application of bioflocculant in microalgae concentration has attracted more and more interests (Bukhari et al. 2020; Lei et al. 2015; Li et al. 2016b; Liu et al. 2015a, 2017a; Ndikubwimana et al. 2016; Sarang and Nerurkar 2020; Sivasankar et al. 2020; Sun et al. 2015a, b; Wan et al. 2013; Wang et al. 2015; Xu et al. 2018b; Zou et al. 2018). With the increasing attention to environmental protection and safety, microbial flocculants have been used in many industrial fields, such as wastewater treatment (Agunbiade et al. 2017; Chaisorn et al. 2016; Guo et al. 2013; Li et al. 2013; Liu et al. 2016b, 2019, 2020; Luo et al. 2014, 2016; Ma et al. 2020; Pu et al. 2014, 2018; Sajayan et al. 2017; Zhang et al. 2021; Zhong et al. 2020), nanoparticle synthesis (Dlamini et al. 2019, 2020; Manivasagan et al. 2015; Muthulakshmi et al. 2017, 2019; Rasulov et al. 2016a, b; Sathiyanarayanan et al. 2013; Zaki et al. 2014), heavy metal ion adsorption (Agunbiade et al. 2019; Ayangbenro et al. 2019; Cao et al. 2015; Chen et al. 2016; Feng et al. 2013; Gomaa 2012; Guo 2015; Guo and Chen 2017a; Guo and Yu 2014; Huang et al. 2019; Li et al. 2016a; Pathak et al. 2017; Pu et al. 2020; Subudhi et al. 2016; Vimala et al. 2020; Yan et al. 2020), activated sludge dewatering (Guo and Ma 2015; Guo et al. 2015b, d; Liu et al. 2014; Yang et al. 2012, 2017), dye decolorization (Wang et al. 2020; Xia et al. 2018), pathogen removal from water (Zhao et al. 2013), and membrane fouling reduction (Deng et al. 2015). Therefore, microbial flocculants gradually replace the traditional inorganic and organic polymeric flocculants which will become an inevitable trend. In Table 1, we summarize the industrial applications of microbial flocculants. At present, compared with the traditional flocculants, the market share of microbial flocculant products is still relatively low due to its high production cost resulted by fermentation medium and fermentation process (Liu et al. 2016b, 2017a, 2019, 2020; Salehizadeh and Yan 2014), which restricts the large-scale application of microbial flocculants.

To reduce the production and application cost of microbial flocculants, a series of efforts and strategies have been carried out. Especially in the last 10 years, some exciting research progresses have been achieved. This paper summarizes the latest research advances on the screening of high-yield strains, the exploitation of cheap alternative medium, the construction of genetic engineering strain, the extraction and preservation methods, and other strategies to reduce the production and application cost of microbial flocculants, and put forward the new development trend and research direction of microbial flocculant, thereby promoting its large-scale production and applications.

\section{Efforts to reduce the production and application cost of microbial flocculants}

Screening of high-yield strains

One of the effective strategies to reduce the production cost of microbial flocculants is to screen high-yield strains and optimize their fermentation conditions, so it has always been a hot research work in this field. At present, the reported microbial flocculants producing strains mainly include bacteria (Salehizadeh and Yan 2014), actinomycetes (Nwodo et al. 2014), fungi (Aljuboori et al. 2015), and algae (Tiwari et al. 2015), among which bacterial strains are the most common source for the production of microbial flocculants. So far, more than 100 strains have been reported to be able to produce microbial flocculants, some of which show high yield or 
Table 1 Application fields of microbial flocculants

\begin{tabular}{|c|c|c|c|c|}
\hline Applications & Strains or sources & Dosage & Descriptions & Ref. \\
\hline \multirow[t]{15}{*}{ Biomass harvest } & Bacillus agaradhaerens & $8 \mathrm{mg} / \mathrm{L}$ & $\begin{array}{l}\text { Microalgae harvest, FR of } 80.63 \% \text { to } \\
\text { Chlorella minutissima }\end{array}$ & Liu et al. (2015b) \\
\hline & Enterobacter aerogenes & $13.5 \mathrm{mg} / \mathrm{L}$ & $\begin{array}{l}\text { Microalgae harvest, FR of } 91.68 \text { to } \\
97.21 \% \text { to Microcystis aeruginosa }\end{array}$ & Xu et al. (2018b) \\
\hline & Pseudomonas aeruginosa & $1.75 \mathrm{mg} / \mathrm{L}$ & $\begin{array}{l}\text { Microalgae harvest, } F R \text { of } 100 \% \text { to } \\
\text { Microcystis aeruginosa }\end{array}$ & Sun et al. $(2015 a, b)$ \\
\hline & Cobetia marina & $20 \mathrm{mg} / \mathrm{L}$ & $\begin{array}{l}\text { Microalgae harvest, } \mathrm{FR} \text { of } 92.7 \% \text { to } \\
\text { Chlorella vulgaris }\end{array}$ & Lei et al. (2015) \\
\hline & Shinella albus & $30 \mathrm{mg} / \mathrm{L}$ & $\begin{array}{l}\text { Microalgae harvest, FR of } 85.65 \% \text { to } \\
\text { Chlorella vulgaris }\end{array}$ & Li et al. (2016b) \\
\hline & Streptomyces sp. & $5 \mathrm{~g} / \mathrm{L}$ & $\begin{array}{l}\text { Microalgae harvest, FR of } 99.18 \% \text { to } \\
\text { Nannochloropsis }\end{array}$ & Sivasankar et al. (2020) \\
\hline & Bacillus marisflavi & $100 \mathrm{mg} / \mathrm{L}$ & $\begin{array}{l}\text { Microalgae harvest, } \mathrm{FR} \text { of } 90 \% \text { to } \\
\text { Chlorella vulgaris }\end{array}$ & Bukhari et al. (2020) \\
\hline & Cellulosimicrobium cellulans & $250 \mathrm{~mL} / \mathrm{L}$ & $\begin{array}{l}\text { Microalgae harvest, } F R \text { of } 99.0 \% \text { to } \\
\text { Chlamydomonas reinhardtii }\end{array}$ & Liu et al. (2015b) \\
\hline & Bacillus licheniformis & $2.5 \mathrm{~mL} / \mathrm{L}$ & $\begin{array}{l}\text { Microalgae harvest, } F R \text { of } 99 \% \text { to } \\
\text { Desmodesmus brasiliensis }\end{array}$ & Ndikubwimana et al. (2016) \\
\hline & Bacillus amyloliquefaciens & $243 \mathrm{mg} / \mathrm{L}$ & $\begin{array}{l}\text { Microalgae harvest, FR of } 87.98 \% \text { to } \\
\text { Microcystis aeruginosa }\end{array}$ & Sun et al. $(2015 a, b)$ \\
\hline & Citrobacter sp. & $12.7 \mathrm{mg} / \mathrm{L}$ & $\begin{array}{l}\text { Microalgae harvest, FR of 95\% to Micro- } \\
\text { cystis aeruginosa }\end{array}$ & Xu et al. (2017) \\
\hline & Pseudomonas boreopolis & $80 \mathrm{mg} / \mathrm{L}$ & $\begin{array}{l}\text { Microalgae harvest, FR of } 95.7 \% \text { to } \\
\text { Scenedesmus abundans }\end{array}$ & Guo et al. $(2018 a, b)$ \\
\hline & Solibacillus silvestris & $1.1 \mathrm{~g} / \mathrm{L}$ & $\begin{array}{l}\text { Microalgae harvest, FR of } 85.7 \% \text { to } \\
\text { Nannochloropsis oceanica }\end{array}$ & Wan et al. (2013) \\
\hline & Cloacibacterium normanense & $5.8 \mathrm{mg} / \mathrm{g}$ & $\begin{array}{l}\text { Yeast harvest, FR of } 74.07 \% \text { to Yarrowia } \\
\text { lipolytica }\end{array}$ & Yellapu et al. (2019) \\
\hline & Paecilomyces sp. & $700 \mathrm{mg} / \mathrm{L}$ & $\begin{array}{l}\text { Yeast harvest, FR of 95\% to Trichos- } \\
\text { poron fermentans }\end{array}$ & Qiao et al. (2019) \\
\hline \multirow[t]{15}{*}{ Metal ion removal } & Turicibacter sanguinis & $500 \mathrm{mg} / \mathrm{L}$ & Remove $86.1 \%$ arsenite from solution & Cao et al. (2015) \\
\hline & Stenotrophomonas maltophilia & $40 \mathrm{mg} / \mathrm{L}$ & Remove $81.4 \% \mathrm{Cd}^{2+}$ from solution & Chen et al. (2016) \\
\hline & Bacillus megaterium & $0.005 \%$ & Remove $99.2 \%$ arsenite from solution & Guo and Chen (2017a) \\
\hline & Pseudomonas koreensis & $1 \mathrm{~g} / \mathrm{L}$ & $\begin{array}{l}\text { Remove } 51.2 \% \mathrm{Cd}^{2+}, 52.5 \% \mathrm{Cr}^{6+} \text { and } \\
80.5 \% \mathrm{~Pb}^{2+} \text { from solution }\end{array}$ & Ayangbenro et al. (2019) \\
\hline & Bacillus megaterium & $1.25 \mathrm{~g} / \mathrm{L}$ & $\begin{array}{l}\text { Remove } 82.64 \% \mathrm{~Pb}^{2+}, 51.82 \% \mathrm{Zn}^{2+} \\
\text { and } 33 \% \mathrm{Ni}^{2+} \text { from solution }\end{array}$ & Pu et al. (2020) \\
\hline & Achromobacter xylosoxidans & $1 \mathrm{~g} / \mathrm{L}$ & Absorb over $95 \% \mathrm{~Pb}^{2+}$ from solution & Subudhi et al. (2016) \\
\hline & $\begin{array}{l}\text { Enterococcus faecalis, Proteus mirabilis, } \\
\text { Lysini sp. }\end{array}$ & $28 \mathrm{mg} / \mathrm{L}$ & $\begin{array}{c}\text { Adsorb } 95 \% \mathrm{Cu}^{2+}, 72 \% \mathrm{Zn}^{2+}, 58 \% \\
\mathrm{Hg}^{2+}, 92 \% \mathrm{Cd}^{2+} \text { from solution }\end{array}$ & Vimala et al. (2020) \\
\hline & Rhodococcus erythropolis & $0.035 \%$ & Remove $96.9 \% \mathrm{Cu}^{2+}$ from solution & Guo (2015) \\
\hline & Terrabacter sp. & $500 \mathrm{mg} / \mathrm{L}$ & $\begin{array}{l}\text { Remove } 77.7 \% \mathrm{Fe}^{3+}, 74.8 \% \mathrm{Al}^{3+} \\
61.9 \% \mathrm{Mn}^{2+}, 57.6 \% \mathrm{Zn}^{2+} \text { from dairy } \\
\text { wastewater }\end{array}$ & Agunbiade et al. (2019) \\
\hline & From activated sludge & $6 \mathrm{mg} / \mathrm{L}$ & Remove $98.5 \%$ of $\mathrm{Pb}^{2+}$ from solution & Yan et al. (2020) \\
\hline & Pseudomonas aeruginosa & 100 ppm & $\begin{array}{c}\text { Absorb } 79.7 \% \mathrm{~Pb}^{2+}, 79.9 \% \mathrm{Cd}^{2+}, 72.9 \% \\
\mathrm{As}^{5+} \text { and } 80.6 \% \mathrm{Zn}^{2+} \text { from solution }\end{array}$ & Gomaa (2012) \\
\hline & Paenibacillus elgii & $1 \mathrm{~g} / \mathrm{L}$ & $\begin{array}{l}\text { Remove } 53 \% \mathrm{Cu}^{2+}, 49 \% \mathrm{Co}^{2+}, 60 \% \\
\mathrm{~Pb}^{2+}, 72 \% \mathrm{Al}^{3+} \text { from solution }\end{array}$ & Li et al. (2013) \\
\hline & Pseudomonas aeruginosastrain & $20 \mathrm{mg} / \mathrm{L}$ & Remove $79.29 \% \mathrm{Ni}^{2+}$ from solution & Pathak et al. (2017) \\
\hline & $\begin{array}{l}\text { Bacillus sphaericus and Rhizobium } \\
\text { radiobacter }\end{array}$ & $28 \mathrm{mg} / \mathrm{L}$ & Remove $92.95 \% \mathrm{Al}^{3+}$ of river water & Li et al. (2016a) \\
\hline & Paenibacillus polymyxa & $0.006 \%$ & Remove $99.85 \% \mathrm{~Pb}^{2+}$ from solution & Feng et al. (2013) \\
\hline
\end{tabular}


Table 1 (continued)

\begin{tabular}{|c|c|c|c|c|}
\hline Applications & Strains or sources & Dosage & Descriptions & Ref. \\
\hline \multirow[t]{5}{*}{ Sludge dewatering } & Rhodococcus erythropolis & $10.5 \mathrm{~g} / \mathrm{kg}$ & $\begin{array}{l}\text { DS and SRF of sludge appeared as } \\
24.1 \% \text { and } 3.0 \times 10^{12} \mathrm{~m} / \mathrm{kg}\end{array}$ & Guo and Chen (2017b) \\
\hline & From pre-treated sludge & $1.6 \mathrm{~g} / \mathrm{L}$ & $\begin{array}{l}\text { DS and SRF of the sludge reached } \\
22.5 \% \text { and } 3.4 \times 10^{12} \mathrm{~m} / \mathrm{kg}\end{array}$ & Guo and Ma (2015) \\
\hline & Paenibacillus polymyxa & $1.5 \mathrm{~g} / \mathrm{L}$ & $\begin{array}{l}\text { DS and SRF of activated sludge } \\
\text { reached } 20.8 \% \text { and } 3.9 \times 10^{12} \mathrm{~m} / \mathrm{kg}\end{array}$ & Guo et al. (2015d) \\
\hline & Klebsiella sp. & $6 \mathrm{~g} / \mathrm{kg}$ & $\begin{array}{l}\text { DS and SRF of sludge reached } 17.5 \% \\
\text { and } 3.36 \times 10^{12} \mathrm{~m} / \mathrm{kg}\end{array}$ & Yang et al. (2012) \\
\hline & Azotobacter chroococcum & $80 \mathrm{mg} / \mathrm{L}$ & $\begin{array}{l}\text { Dewatering of coal waste slurry, FR of } \\
83 \% \text { to coal waste slurry }\end{array}$ & Yang et al. (2017) \\
\hline \multirow[t]{21}{*}{ Wastewater treatment } & Bacillus agaradhaerens & $6 \mathrm{mg} / \mathrm{L}$ & $\begin{array}{l}\text { Remove } 93.1 \% \text { turbidity from straw } \\
\text { ash-washing wastewater }\end{array}$ & Liu et al. (2020) \\
\hline & Diaphorobacter nitroreducens & $831 \mathrm{mg} / \mathrm{L}$ & $\begin{array}{l}\text { Remove } 96 \% \text { turbidity, } 79 \% \text { COD, } \\
59 \% \text { lignin, } 63 \% \text { sugar from pulping } \\
\text { wastewater }\end{array}$ & Zhong et al. (2020) \\
\hline & Bacillus cereus & $10 \mathrm{mg} / \mathrm{L}$ & $\begin{array}{l}\text { Reduce } 62 \% \text { COD, } 55 \% \text { BOD, } 76 \% \text { TDS, } \\
74 \% \text { TSS from distillery effluent }\end{array}$ & Sajayan et al. (2017) \\
\hline & Bacillus subtilis & $60 \mathrm{mg} / \mathrm{L}$ & $\begin{array}{l}\text { Remove } 27.3 \% \text { SS of palm oil mill } \\
\text { effluent }\end{array}$ & Chaisorn et al. (2016) \\
\hline & From pre-treated sludge & $20 \mathrm{mg} / \mathrm{L}$ & $\begin{array}{l}\text { Remove } 45.2 \% \text { COD, } 41.8 \% \text { ammo- } \\
\text { nium, } 74.6 \% \text { turbidity from swine } \\
\text { wastewater }\end{array}$ & Guo and Ma (2015) \\
\hline & Pseudomonas veronii & $2.83 \mathrm{mg} / \mathrm{L}$ & $\begin{array}{l}\text { Remove } 92.51 \% \text { turbidity from ash } \\
\text { flushing wastewater }\end{array}$ & Liu et al. $(2016 a, b)$ \\
\hline & Bacillus agaradhaerens & $9 \mathrm{mg} / \mathrm{L}$ & $\begin{array}{l}\text { Remove } 92.35 \% \text { turbidity from mineral } \\
\text { processing wastewater }\end{array}$ & Liu et al. (2019) \\
\hline & Paenibacillus polymyxa & $30 \mathrm{mg} / \mathrm{L}$ & $\begin{array}{l}\text { Remove } 49.5 \% \text { COD and } 74.6 \% \text { turbid- } \\
\text { ity from potato starch wastewater }\end{array}$ & Guo et al. (2015a) \\
\hline & Terrabacter sp. & 500 mg/L & $\begin{array}{l}\text { Remove } 54.1 \% \text { COD, } 63.3 \% \text { BOD, } 66.6 \% \\
\text { SS, } 75.6 \% \text { nitrate, } 89.7 \% \text { turbidity of } \\
\text { dairy wastewater }\end{array}$ & Agunbiade et al. (2019) \\
\hline & Enterobacter sp. & $1000 \mathrm{mg} / \mathrm{L}$ & $\begin{array}{l}\text { Remove } 85 \% \text { chroma and } 52 \% \text { SS of } \\
\text { fracturing flowback water }\end{array}$ & Ma et al. (2020) \\
\hline & Bacillus fusiformis & 110 mg/L & $\begin{array}{l}\text { Remove } 22.7 \% \text { total nitrogen, } 28.5 \% \\
\text { COD, } 20.4 \% \text { colority from tannery } \\
\text { wastewater }\end{array}$ & Zhao et al. (2016) \\
\hline & Arthrobacter humicola & 800 mg/L & $\begin{array}{l}\text { Remove } 65.7 \% \text { COD, } 63.5 \% \text { BOD, } 55.7 \% \\
\text { SS, } 71.4 \% \text { nitrate, } 81.3 \% \text { turbidity of } \\
\text { sewage wastewater }\end{array}$ & Agunbiade et al. (2017) \\
\hline & Alteromonas sp. & 200 mg/L & $\begin{array}{l}\text { Remove } 98.5 \% \text { congo red, } 97.9 \% \text { direct } \\
\text { black, } 72.3 \% \text { methylene blue from } \\
\text { dye wastewater }\end{array}$ & Chen et al. (2017a) \\
\hline & Aspergillus niger & $3.78 \mathrm{mg} / \mathrm{L}$ & $\begin{array}{l}\text { Remove } 91.15 \% \text { COD and } 60.22 \% \text { tur- } \\
\text { bidity from potato starch wastewater }\end{array}$ & Pu et al. (2018) \\
\hline & Klebsiella variicola & 333 mg/L & $\begin{array}{l}\text { Achieve } 84.7 \% \text { decolorization effi- } \\
\text { ciency to methylene blue solution }\end{array}$ & Xia et al. (2018) \\
\hline & Rhodococcus sp. & $24 \mathrm{mg} / \mathrm{L}$ & $\begin{array}{l}\text { Remove } 87.9 \% \text { COD, } 86.9 \% \text { ammonium } \\
\text { and } 94.8 \% \text { turbidity from swine } \\
\text { wastewater }\end{array}$ & Guo et al. (2013) \\
\hline & Paenibacillus elgii & $30 \mathrm{~mL} / \mathrm{L}$ & $\begin{array}{l}\text { Remove } 68 \% \text { COD, } 83 \% \text { turbidity, } 88 \% \\
\text { color from real wastewater }\end{array}$ & Li et al. (2013) \\
\hline & Rhizopus sp. & $0.1 \mathrm{~mL} / \mathrm{L}$ & $\begin{array}{l}\text { Remove } 54.09 \% \text { COD and } 92.11 \% \text { tur- } \\
\text { bidity from potato starch wastewater }\end{array}$ & Pu et al. (2014) \\
\hline & Aspergillus niger & $35 \mathrm{mg} / \mathrm{L}$ & Remove $63 \%$ turbidity of river water & Aljuboori et al. (2014) \\
\hline & Klebsiella sp. & $5 \mathrm{mg} / \mathrm{L}$ & $\begin{array}{l}\text { Remove } 53.27 \% \text { sulfamethoxazole in } \\
\text { domestic wastewater }\end{array}$ & Xing et al. (2013) \\
\hline & Klebsiella pneumoniae & 44 mg/L & Remove $72 \%$ TSS from raw wastewater & Nie et al. (2011) \\
\hline
\end{tabular}


Table 1 (continued)

\begin{tabular}{|c|c|c|c|c|}
\hline Applications & Strains or sources & Dosage & Descriptions & Ref. \\
\hline & Sphingomonas yabuuchiae & $50 \mathrm{mg} / \mathrm{L}$ & $\begin{array}{l}\text { Remove } 87 \% \text { estrone, } 92 \% \text { estradiol, } \\
88 \% \text { ethinylestradiol, } 96 \% \text { estriol from } \\
\text { estrogen solution }\end{array}$ & Zhong et al. (2014) \\
\hline & Oceanobacillus polygoni & $4 \mathrm{~g} / \mathrm{L}$ & $\begin{array}{l}\text { Remove } 46.49 \% \text { SS and } 91.08 \% \text { turbid- } \\
\text { ity from tannery wastewater }\end{array}$ & Li et al. (2017) \\
\hline & Bacillus salmalaya & $60 \mathrm{mg} / \mathrm{L}$ & $\begin{array}{l}\text { Remove } 81.3 \% \mathrm{Zn}^{2+}, 78.6 \% \mathrm{As}_{1} 77.9 \% \\
\mathrm{~Pb}^{2+}, 76.1 \% \mathrm{Cu}^{2+}, 68.7 \% \mathrm{Cd}^{2+} \text { from } \\
\text { synthetic wastewater }\end{array}$ & Tawila et al. (2019) \\
\hline & Bacillus sp. & $2 \%$ & $\begin{array}{l}\text { Remove } 82.8 \% \text { color, } 92.5 \% \text { COD, } \\
73.6 \% \mathrm{TSS}, 81.9 \% \mathrm{Cl}^{-} \text {from dyeing } \\
\text { wastewater }\end{array}$ & Bisht and Lal (2019) \\
\hline & Haloplanus vescus & $150 \mathrm{mg} / \mathrm{L}$ & $\begin{array}{l}\text { Removed } 81.86 \text { COD and } 95.07 \% \\
\text { chroma from dye wastewater }\end{array}$ & Zhong et al. (2016) \\
\hline & Cellulomonas taurus & & $\begin{array}{l}\text { Removed } 71.05 \% \text { COD, } 18.22 \text { ammonia } \\
\text { nitrogen from pig farm wastewater }\end{array}$ & Zhang et al. (2021) \\
\hline & Bacillus sp. & $20 \mathrm{mg} / \mathrm{L}$ & $\begin{array}{l}\text { Remove } 47 \% \text { COD and } 89 \% \text { TSS from } \\
\text { municipal wastewater }\end{array}$ & Kanmani and Yuvapriya (2018) \\
\hline \multirow[t]{8}{*}{ Nanoparticle synthesis } & Bacillus sp. & & $\begin{array}{l}\text { Bioflocculant diffused cellulose in } \\
\mathrm{AgNO}_{3} \text { solution, generated nanopar- } \\
\text { ticles AgNPs }\end{array}$ & Muthulakshmi et al. (2017) \\
\hline & Streptomyces sp. & & $\begin{array}{l}\text { Add bioflocculant to } \mathrm{AgNO}_{3} \text { solution, } \\
\text { produced silver nanoparticles }\end{array}$ & Manivasagan et al. (2015) \\
\hline & Bradyrhizobium japonicum & & $\begin{array}{l}\text { Add bioflocculant to } \mathrm{AgNO}_{3} \text { solution, } \\
\text { produced nanoparticles AgCl-NPs }\end{array}$ & Rasulov et al. (2016a) \\
\hline & Bacillus sp. & & $\begin{array}{l}\text { Bioflocculant diffused cellulose in } \\
\mathrm{CuSO}_{4} \text { solution, obtained nanoparti- } \\
\text { cles (CuNPs) }\end{array}$ & Muthulakshmi et al. (2019) \\
\hline & Alcalegenis faecalis & $2.5 \mathrm{~g} / \mathrm{L}$ & $\begin{array}{l}\text { Add bioflocculant in } \mathrm{CuSO}_{4} \text { solution, } \\
\text { synthesized nanoparticles CuNPs }\end{array}$ & Dlamini et al. (2020) \\
\hline & Azotobacter chroococcum & & $\begin{array}{l}\text { Bioflocculant exposed to } \mathrm{AgNO}_{3} \\
\text { solution, produced nanoparticles } \\
\text { AgCl-NPs }\end{array}$ & Rasulov et al. (2016b) \\
\hline & Bacillus subtilis & $5 \%$ & $\begin{array}{l}\text { Add } \mathrm{AgNO}_{3} \text { to bioflocculant solution, } \\
\text { generated nanoparticles AgNPs }\end{array}$ & Sathiyanarayanan et al. (2013) \\
\hline & Bacillus mojavensis & $10 \%$ & $\begin{array}{l}\text { Add } \mathrm{AgNO}_{3} \text { to bioflocculant solution, } \\
\text { synthesize nanoparticles AgNPs }\end{array}$ & Zaki et al. (2014) \\
\hline \multirow[t]{4}{*}{ Other applications } & Bacillus subtilis & $0.1-1 \mathrm{~g} / \mathrm{L}$ & $\begin{array}{l}\text { Exhibited antibacterial, antioxidant, } \\
\text { and anti-inflammatory potential }\end{array}$ & Giri et al. (2019) \\
\hline & Stenotrophomonas maltophilia & $0.001-1 \mathrm{~g} / \mathrm{L}$ & Used as hemostasis agent & Zhao et al. (2017) \\
\hline & Paenibacillus jamilae & $100 \mathrm{mg} / \mathrm{L}$ & Used as hemostasis in clinical settings & Zhong et al. (2018) \\
\hline & Enterococcus faecalis & $11.57 \mathrm{mg} / \mathrm{L}$ & $\begin{array}{l}\text { Recover graphene oxide, FR over } 90 \% \\
\text { to graphene oxide in water }\end{array}$ & Xu et al. (2018a) \\
\hline
\end{tabular}

FR flocculating rate, SS suspended solids, DS dry solids, SRF specific resistance to filtration, COD chemical oxygen demand, BOD biological oxygen demand, TSS total suspended solids

good application prospects, including Lipomyces starkeyi U9 (Yu et al. 2020b), Alteromonas sp. (Chen et al. 2017a), Bacillus agaradhaerens C9 (Liu et al. 2015a, 2017a, 2019), Solibacillus silvestris W01 (Wan et al. 2013), Paenibacillus elgii B69 (Li et al. 2013), Agrobacterium sp. M-503 (Li et al. 2010), Klebsiella oxytoca GS-4-08 (Yu et al. 2016), Paenibacillus mucilaginosus (Tang et al. 2014a), Achromobacter sp. TERI-IASST N (Subudhi et al. 2014), Bacillus marisflavi NA8 (Bukhari et al. 2020), and Bacillus subtilis MSBN17 (Sathiyanarayanan et al. 2013). Tables 2 and 3 summarize the fermentation conditions and yields of the reported strains. Furthermore, screening strains that can produce microbial flocculant under low nutritional condition is also an effective strategy to reduce the production cost of microbial flocculants. For example, Chryseobacterium daeguense W6 can produce microbial flocculant at low nutrient condition. In the early stage of fermentation, the strain W6 grew rapidly and the flocculating activity of fermentation broth was low; however, in the late stage of fermentation, the cell lysis of strain W6 
Table 2 Microbial flocculant producing strains and their composition, extract method, and yield

\begin{tabular}{|c|c|c|c|c|c|}
\hline Strains & $\begin{array}{l}\text { Carbon and nitrogen sources } \\
\text { (g/L) }\end{array}$ & Components & Extracts & Yields (g/L) & Ref. \\
\hline Bacillus agaradhaerens & Glucose 10, YE 10 & Ps $65.4 \%, \operatorname{Pr} 4.7 \%$, NA $1.6 \%$ & EP & 4.65 & Liu et al. (2015a) \\
\hline Streptomyces sp. & Palm jaggery 18.73, YE 2.07 & Ps & EP & & Manivasagan et al. (2015) \\
\hline Bradyrhizobium japonicum & Sucrose 25, YE 2.5 & Ps & EP & & Rasulov et al. (2016a) \\
\hline Streptomyces sp. & YE 2.5, palm jiggery $20, \mathrm{NH}_{4} \mathrm{NO}_{2} 1$ & Ps $86.9 \%, \operatorname{Pr} 12.8 \%$ & $A P, I E C, G F C$ & 4.94 & Sivasankar et al. (2020) \\
\hline Alcaligenes faecalis & Maltose 20 , rea 1.2 & Ps $88.6 \%, \operatorname{Pr} 9.5 \%$ & EP & 4.00 & Maliehe et al. (2019) \\
\hline Bacillus sp. & $\begin{array}{l}\text { Glucose } 20,\left(\mathrm{NH}_{4}\right)_{2} \mathrm{SO}_{4} 0.3 \text {, urea } 0.5 \text {, } \\
\text { YE } 0.5\end{array}$ & Ps $76 \%, \operatorname{Pr} 14 \%$ & EP & 1.60 & Okaiyeto et al. (2015b) \\
\hline Alteromonas sp. & Glucose 30 , wheat flour 1.5 & Ps $69.6 \%, \operatorname{Pr} 21.5 \%$ & EP & 11.18 & Chen et al. (2017a) \\
\hline Bacillus licheniformis & Sucrose 10, YE 1, urea 1 & Ps $89 \%, \operatorname{Pr} 11 \%$ & EP & 2.93 & Xiong et al. (2010) \\
\hline Bacillus thuringiensis & Beef extract 3.0, peptone 10.0 & Ps & EP & 20.19 & Wang et al. (2011) \\
\hline Lipomyces starkeyi & Glucose 100 , polypeptone 7.0 & Ps & EP & 53.50 & Yu et al. (2020b) \\
\hline Streptomyces, Cellulomonas & Sucrose 16 , peptone 1.5 & Ps $34.4 \%, \operatorname{Pr} 18.5 \%$ & EP & 4.45 & Nwodo et al. (2014) \\
\hline Chryseobacterium daeguense & Glucose 1, Tryptone 2 & Ps $13 \%, \operatorname{Pr} 32 \%$, NA $6.8 \%$ & EP & 0.89 & Liu et al. (2010) \\
\hline Bacillus mojavensis & L-Glutamic acid 20, $\mathrm{NH}_{4} \mathrm{Cl} 7$ & Ps $98.4 \%, \operatorname{Pr} 1.6 \%$ & EP & 5.20 & Elkady et al. (2011) \\
\hline Aspergillus flavus & Sucrose 30 , peptone 3 & Ps $69.7 \%, \operatorname{Pr} 28.5 \%$ & EP & 0.40 & Aljuboori et al. (2013) \\
\hline Solibacillus silvestris & Maltose 1.9, YE 11 & Ps $75.1 \%, \operatorname{Pr} 24.9 \%$ & AP & 0.40 & Wan et al. (2013) \\
\hline Paenibacillus elgii & Sucrose 51.3, peptone 6.7, YE 0.47 & Ps & EP & 25.63 & Li et al. (2013) \\
\hline Virgibacillus & $\begin{array}{l}\text { Glucose } 20 \text {, urea 0.5, YE 0.5, } \\
\left(\mathrm{NH}_{4}\right)_{2} \mathrm{SO}_{4} 0.2\end{array}$ & Ps & EP & 2.43 & Sekelwa et al. (2013) \\
\hline Agrobacterium sp. & $\begin{array}{l}\text { Sucrose 20, YE 0.5, urea 0.5, } \\
\left(\mathrm{NH}_{4}\right)_{2} \mathrm{SO}_{4} 0.2\end{array}$ & Ps $97 \%, \operatorname{Pr} 3.0 \%$ & EP, IEC, GFC & 14.90 & Li et al. (2010) \\
\hline Achromobacter sp. & Sucrose 10 , urea 10 & Ps $57 \%, \operatorname{Pr} 13 \%$ & EP & 10.50 & Subudhi et al. (2014) \\
\hline Enterobacter sp. & Glucose $10, \mathrm{NaNO}_{3} 1$ & Ps $91.7 \%, \operatorname{Pr} 1.8 \%$ & $E P, C T A B-p$ & 0.066 & Tang et al. (2014b) \\
\hline $\begin{array}{l}\text { Methylobacterium sp. and } \\
\text { Actinobacterium sp. }\end{array}$ & $\begin{array}{l}\text { Glucose } 20,\left(\mathrm{NH}_{4}\right)_{2} \mathrm{SO}_{4} 0.2, \text { urea } 0.2 \text {, } \\
\text { YE } 0.5\end{array}$ & & EP & 8.20 & Luvuyo et al. (2013) \\
\hline Pseudomonas aeruginosa & $\begin{array}{l}\text { Sucrose } 5 \text {, glucose 2, maltose 2, YE } \\
5, \mathrm{NH}_{4} \mathrm{Cl} 1.5\end{array}$ & Ps $71.7 \%$, Pr $16.4 \%$, NA $2.1 \%$ & EP & 3.58 & Sun et al. (2015a) \\
\hline Paenibacillus mucilaginosus & Sucrose 20, YE 0.5 & Ps & $E P, I E C, G F C$ & 1.33 & Tang et al. (2014a) \\
\hline
\end{tabular}

$Y E$ yeast extract, $P$ s polysaccharide, Pr protein, NA nucleic acid, EP ethanol precipitate, AP acetone precipitate, IEC lon exchange chromatography, GFC Gel filtration chromatography, CTAB-p cetyltrimethyl ammonium bromide precipitate

occurred rapidly and released microbial flocculant product (Liu et al. 2010). In addition, the flocculating activity of some microbial flocculants depends on the activation of metal ions. Therefore, selecting the strains that can produce microbial flocculant independent of metal ions is conducive to reducing the application cost of microbial flocculants and avoiding the secondary pollution caused by the addition of metal ions (Liu et al. 2010; Tang et al. 2014b; Yin et al. 2014). The reported strains producing microbial flocculant independent of metal ions are listed in Table 3. The dependence of flocculating activity on metal ions generally depends on the composition of microbial flocculants. Most positively charged microbial flocculants do not require metal ions and their flocculating activity is mainly achieved by charge neutralization with negatively charged suspended particles (Liu et al. 2015c; Mohammed and Dagang 2019b).

\section{Construction of genetically engineered strains}

The construction of genetically engineered strains is an efficient approach to improve the yield of microbial flocculant and further reduce its production cost. However, only a few microbial flocculant producing strains have been genetically engineered. In Bacillus licheniformis CGMCC2876, a polysaccharide-related gene cluster eps $A-O$ and regulatory genes $\sin R$ and $\operatorname{slr} R$ were identified through genome sequencing and comparative genomics analysis (Chen et al. 2017b). Both EpsE and EpsF are glucosyltransferases involved in the conversion of UDP-glucose into polysaccharide. EpsD is a glucuronyltransferase that utilizes UDP-glucuronic acid as substrate. Overexpression of epsDEF in B. licheniformis CGMCC2876 enhanced the flocculating activity by $90 \%$ and increased the yield of polysaccharide flocculant by $27.8 \%$ compared to the original strain (Chen et al. 2017b). Overexpression of the UDP-glucose pyrophosphorylase gene in B. licheniformis CGMCC2876 not only increased 
Table 3 Correlation between composition of microbial flocculant with its thermal stability, metal ion dependence and flocculating mechanism

\begin{tabular}{|c|c|c|c|c|c|}
\hline Strains & Compositions & Stability $\left({ }^{\circ} \mathrm{C}\right)$ & Metal ions & Mechanisms & Ref. \\
\hline Bacillus agaradhaerens & $\begin{array}{l}\text { Ps } 65.4 \%, \operatorname{Pr} 4.7 \% \text {, NA } \\
\quad 1.6 \%\end{array}$ & $3-63$ & $\mathrm{Ca}^{2+}$-independent & & Liu et al. (2015a) \\
\hline Bacillus aryabhattai & Glycoprotein & $40-80$ & Activated by $\mathrm{Ca}^{2+}$ & & Abd El-Salam et al. (2017) \\
\hline Bacillus subtilis & Ps $88.3 \%, \operatorname{Pr} 10.1 \%$ & $10-100$ & Activated by $\mathrm{Ca}^{2+}$ & & Giri et al. (2015) \\
\hline Bacillus megaterium & Ps $85.5 \%, \operatorname{Pr} 14.3 \%$ & $10-120$ & $\mathrm{Ca}^{2+}$-independent & $\begin{array}{l}\text { Bridging, charge neutrali- } \\
\text { zation }\end{array}$ & Guo and Chen (2017a) \\
\hline Rhodococcus erythropolis & Ps $95.6 \%, \operatorname{Pr} 4.4 \%$ & $10-120$ & $\mathrm{Ca}^{2+}$-independent & $\begin{array}{l}\text { Bridging, charge neutrali- } \\
\text { zation }\end{array}$ & Guo et al. (2015c) \\
\hline $\begin{array}{l}\text { Diaphorobacter nitrore- } \\
\text { ducens }\end{array}$ & Ps $73.9 \%, \operatorname{Pr} 24.1 \%$ & $20-80$ & Activated by $\mathrm{Ca}^{2+}, \mathrm{Mg}^{2+}$ & Charge neutralization & Zhong et al. (2020) \\
\hline Klebsiella sp. & Ps $84.6 \%, \operatorname{Pr} 11.1 \%$ & $30-100$ & & Bridging mechanism & Liu et al. (2013) \\
\hline Bacillus cereus & Ps & $30-100$ & & & Sajayan et al. (2017) \\
\hline Aspergillus flavus & Ps $69.7 \%, \operatorname{Pr} 28.5 \%$ & $5-45$ & Cation-independent & Charge neutralization & Aljuboori et al. (2015) \\
\hline $\begin{array}{l}\text { Sphingomonas yabu- } \\
\text { uchiae }\end{array}$ & Ps $91 \%, \operatorname{Pr} 9 \%$ & $20-80$ & Cation-independent & & Tang et al. (2014b) \\
\hline Paenibacillus jamilae & Ps $89.2 \%, \operatorname{Pr} 6.3 \%$ & $10-100$ & & & Zhong et al. (2018) \\
\hline Bacillus pumilus & Ps $83.1 \%, \operatorname{Pr} 6 \%$ & $50-100$ & Required $\mathrm{Ba}^{2+}$ & Bridging mechanism & Maliehe et al. (2016) \\
\hline $\begin{array}{l}\text { Chryseobacterium dae- } \\
\text { guense }\end{array}$ & $\begin{array}{l}\text { Ps } 13.1 \% \text {, Pr } 32.4 \% \text {, NA } \\
\quad 6.8 \%\end{array}$ & instability & Cation-independent & $\begin{array}{l}\text { Attachment and bridging } \\
\text { neutralization }\end{array}$ & Liu et al. (2015c) \\
\hline Klebsiella sp. & Ps $84.6 \%, \operatorname{Pr} 6.1 \%$ & up to 115 & Cation-independent & Bridging mechanism & Yin et al. (2014) \\
\hline Bacillus marisflavi & Ps $74 \%, \operatorname{Pr} 25 \%$, NA $1 \%$ & $10-100$ & Cation-dependent & & Bukhari et al. (2020) \\
\hline Paenibacillus polymyxa & Ps $96.2 \%$ & $30-110$ & Enhanced by $\mathrm{Ca}^{2+}$ & $\begin{array}{l}\text { Adsorption, bridging, } \\
\text { charge neutralization }\end{array}$ & Guo et al. (2015a) \\
\hline Bacillus toyonensis & Ps $77.8 \%, \operatorname{Pr} 11.5 \%$ & $50-80$ & Increased by $\mathrm{Mn}^{2+}$ & & Okaiyeto et al. (2015a) \\
\hline Bacillus amyloliquefaciens & Ps $57.12 \%$ & & Improved by $\mathrm{Ca}^{2+}$ & Charge neutralization & Sun et al. (2015b) \\
\hline Bacillus pumilus & $\begin{array}{l}\text { Ps } 75.4 \%, \operatorname{Pr} 5.3 \% \text {, NA } \\
\quad 15.4 \%\end{array}$ & up to 100 & $\begin{array}{l}\text { Enhanced by } \mathrm{Ca}^{2+}, \mathrm{Mg}^{2+}, \\
\mathrm{Mn}^{2+}\end{array}$ & & Makapela et al. (2016) \\
\hline Klebsiella variicola & Ps $81.8 \%, \operatorname{Pr} 15.9 \%$ & $20-100$ & $\begin{array}{l}\text { Increased by } \mathrm{Ca}^{2+}, \mathrm{Fe}^{2+} \\
\mathrm{Mg}^{2+}, \mathrm{Mn}^{2+}\end{array}$ & $\begin{array}{l}\text { Bridging, charge neutrali- } \\
\text { zation }\end{array}$ & Xia et al. (2018) \\
\hline $\begin{array}{l}\text { Chlamydomonas rein- } \\
\text { hardtii }\end{array}$ & $\begin{array}{l}\text { Ps } 48 \% \text {, Pr } 42 \% \text {, lipids } \\
8.7 \%\end{array}$ & & Enhanced by $\mathrm{Ca}^{2+}$ & & Zhu et al. (2012) \\
\hline Bacillus megaterium & $\begin{array}{l}\text { Ps } 78.5 \% \text {, Pr } 9.2 \% \text {, others } \\
\quad 12.3 \%\end{array}$ & $20-100$ & $\begin{array}{l}\text { Activated by } \mathrm{Ca}^{2+}, \text { inhib- } \\
\text { ited by } \mathrm{Al}^{3+}, \mathrm{Fe}^{3+}\end{array}$ & Bridging mechanisms & Pu et al. (2020) \\
\hline Pseudomonas aeruginosa & Ps $89 \%, \operatorname{Pr} 27 \%$ & 100 & $\begin{array}{l}\text { Improved by } \mathrm{Ca}^{2+}, \mathrm{K}^{+} \\
\mathrm{Na}^{+}, \mathrm{Zn}^{2+}, \mathrm{Mg}^{2+}, \mathrm{Cu}^{2+} \\
\text { inhibited by } \mathrm{Fe}^{3+}, \mathrm{Al}^{3+}\end{array}$ & & Gomaa (2012) \\
\hline
\end{tabular}

Ps polysaccharide, $\operatorname{Pr}$ protein, NA nucleic acid

the flocculating activity of the recombinant strain by $71 \%$, but also increased yield by $13.3 \%$ compared to the original strain (Chen et al. 2017b). EpsB plays a critical role in the biosynthesis of polysaccharide in B. licheniformis. Overexpressing eps $B$ increased the flocculating activity to $9612.75 \mathrm{U} / \mathrm{mL}$ and the yield to $10.26 \mathrm{~g} / \mathrm{L}$, which enhanced by $224 \%$ and $36.62 \%$, respectively, compared to the original strain (Liu et al. 2017b). Moreover, the tandem expression of phosphoglucomutase $(p g c A)$ and UTP-glucose-1-phosphate uridylyltransferase (gtaB1) was able to increase the yield by $20.77 \%$ and overexpression of eps $A$ was able to enhance the yield by $23.70 \%$ compared to the original strain (Liu et al. 2017b). In addition, in Lipomyces starkeyi V9, overexpression of UDP-glucose dehydrogenase gene was able to improve the exopolysaccharide yield of from 53.5 to $62.1 \mathrm{~g} / \mathrm{L}$ (Yu et al. 2020b).

The lack of mature genetic operation system and complex synthetic regulation mechanism restricts the construction of genetic engineering bacteria of most microbial flocculant producing strains. For the strains with immature genetic operation system or unclear regulation mechanism, it is a good choice to use random mutation technology to improve the production of microbial flocculants. A high-yield mutant of Bacillus cereus was obtained based on mutation effect of $\mathrm{MeV}$ protons and successfully increased the flocculating 
activity of microbial flocculant by more than 20\% (Yang et al. 2007). Random mutation technology generally needs to establish efficient screening models of highyielding mutants, which helps to reduce workload and improve breeding efficiency. For most strains producing polysaccharide flocculant, according to the principle that macromolecular polysaccharide can adsorb Congo red dye, the high-yield mutants can be preliminarily judged based on the strains with redder colony color on the screening medium plate added with Congo red dye, thereby improving the screening efficiency of target mutants.

\section{Search for cheap alternative medium}

The production of microbial flocculant with cheap substitute substrate is not only beneficial to decrease the production cost of microbial flocculants, but also to realize the resource utilization of solid wastes or wastewaters. High concentration organic wastewater is rich in organic substance, which can be used as fermentation carbon source or nitrogen source to cheaply produce microbial flocculants, such as potato starch wastewater (Guo et al. 2015a, d, 2018b; Pu et al. 2014, 2018), brewery wastewater (Ma et al. 2020), corn ethanol wastewater (Xia et al. 2018), swine wastewater (Guo and Chen 2017a), palm oil mill effluent (Aljuboori et al. 2014; Bukhari et al. 2020; Hassimi et al. 2020), livestock wastewater (Peng et al. 2014), ramie biodegumming wastewater (Zhong et al. 2020), phenol-containing wastewater (Chen et al. 2016), and chromotropic acid wastewater (Zhong et al. 2014). In Table 4, we summarize the inexpensive wastes or wastewaters that have been selected as low-cost alternative fermentation medium to produce microbial flocculants.

Lignocellulosic agricultural wastes, such as corn straw, corncob, peanut hull, and rice bran, can be decomposed into reducing sugars, and then converted into other high value-added products through microbial fermentation (Monlau et al. 2014). Therefore, how to efficiently convert these agricultural wastes into valuable products and reduce environmental pollution is one of the current research hotspots (Liu et al. 2015d). To cut down the production cost of microbial flocculants, the hydrolysates of agricultural waste obtained from hot sulfuric acid hydrolysis were used as the carbon source of fermentation medium. For examples, using the hydrolysate of corn straw as the fermentation carbon source of Rhodococcus erythropolis to produce microbial flocculant, the yield reached $2.4 \mathrm{~g} / \mathrm{L}$ (Guo et al. 2015c); the microbial flocculant yield of Ochrobacium ciceri W2 reached $6.2 \mathrm{~g} / \mathrm{L}$ using the hot acidic hydrolysate of rice husk as the carbon source (Wang et al. 2014) and the yield of $3.39 \mathrm{~g} / \mathrm{L}$ microbial flocculant was achieved when peanut hull hydrolyzate was used as carbon source of Pseudomonas veronii L918 (Liu et al. 2016b). However, the hot acidic hydrolyzate of agricultural wastes requires the $\mathrm{pH}$ neutralization using calcium hydroxide before the subsequent fermentation processes (Guo et al. 2015c; Wang et al. 2013), which increases the operation difficulty and the production cost (Liu et al. 2015d). And the hydrolyzates of agricultural wastes always contain toxic by-products, such as phenolic compounds and furan derivatives (Monlau et al. 2014), which inhibit the microbial activities in the fermentation processes (Mussatto and Roberto 2004), and remain in the microbial flocculant products. Therefore, strains that can secrete lignocellulolytic enzymes and simultaneously produce microbial flocculants through directly degrading lignocellulosic biomasses are of academic and practical interests. For example, Cellulosimicrobium cellulans L804 can secrete cellulase and xylanase, and directly convert untreated corn straw into microbial flocculant by one-step integrated biotechnology which integrates the processes of agricultural waste pretreatment, microbial enzyme production, the enzymatic hydrolysis of agricultural waste, and microbial flocculant fermentation (Fig. 1), with a yield of $4.75 \mathrm{~g} / \mathrm{L}$, and exhibits a good flocculating activity to microalgae Chlamydomonas reinhardtii and Chlorella minutissima (Liu et al. 2015d). Compared with the traditional fermentation using pure sugar as carbon source, one-step integrated biotechnology using agricultural waste as carbon source can efficiently decrease the production cost of microbial flocculants; compared with the hydrolysate of agricultural waste as carbon source, it can avoid the toxic by-products produced in the process of hot acid hydrolysis (Monlau et al. 2014; Liu et al. 2015d). However, the optimal fermentation condition ( $\mathrm{pH}$ 9.0) of C. cellulans L804 for microbial flocculant production was different from the optimal condition (pH 6.0) of selfsecreted cellulase and xylanase. The activities at fermentation condition ( $\mathrm{pH} 9.0$ ) of these two enzymes were only half of their optimal conditions at $\mathrm{pH}$ 6.0, which limited the efficiency of enzymatic hydrolysis of corn straw in one-step integrated biotechnology by C. cellulans L804 (Liu et al. 2015d). To solve the condition divergence of enzyme activity and fermentation of microbial flocculant, an alkaline-tolerant Bacillus agaradhaerens C9 was isolated from alkaline lake water (Liu et al. 2015a). The lignocellulose degrading enzyme of $B$. agaradhaerens C9 showed high enzyme activity in the range of $\mathrm{pH} 9.0-10.8$, which was same as the optimal fermentation condition for producing polysaccharide flocculant (Liu et al. 2017a). Therefore, this strain can directly and efficiently convert untreated agricultural wastes (such as corn straw, rice bran, and peanut shell) into microbial flocculant in onestep integrated biotechnology. Moreover, alkaline fermentation condition was able to promote the expansion 
Table 4 Production of microbial flocculants using cheap wastes or waste waters as alternative medium

\begin{tabular}{|c|c|c|c|}
\hline Strains & Fermentation mediums & Yields (g/L) & Ref. \\
\hline Stenotrophomonas maltophilia & $\begin{array}{l}\text { Phenol-containing wastewater with } 800 \mathrm{mg} / \mathrm{L} \text { phenol, dissolved } \\
\text { oxygen concentration } 2 \%\end{array}$ & 4.99 & Chen et al. (2016) \\
\hline Bacillus megaterium & $\begin{array}{l}\text { (mg/L) Swine wastewater contained COD 1065, ammonia 828, and } \\
\text { total phosphorus } 26\end{array}$ & 3.11 & Guo and Chen, (2017a) \\
\hline Rhodococcus erythropolis & $\begin{array}{l}\text { (g/L) Rice stover hydrolyzate, } \mathrm{K}_{2} \mathrm{HPO}_{4} 4, \mathrm{KH}_{2} \mathrm{PO}_{4} 2, \mathrm{MgSO}_{4} 0.2, \mathrm{NaCl} \\
0.1 \text {, urea } 0.5 \text {, yeast extract } 0.5\end{array}$ & 2.37 & Guo et al. (2015c) \\
\hline Bacillus agaradhaerens & $\begin{array}{l}\text { (g/L) Chicken feather 40, glucose 16, } \mathrm{K}_{2} \mathrm{HPO}_{4} 1.4, \mathrm{KH}_{2} \mathrm{PO}_{4} 0.7, \mathrm{NaCl} 0.5 \\
\mathrm{MgSO}_{4} 7 \mathrm{H}_{2} \mathrm{O} 0.1, \mathrm{Na}_{2} \mathrm{CO}_{3} 10\end{array}$ & 2.50 & Liu et al. (2020) \\
\hline Diaphorobacter nitroreducens & $\begin{array}{l}\text { Ramie biodegumming wastewater of } 1500 \mathrm{mg} / \mathrm{L} \text { COD used as } \\
\text { fermentation medium }\end{array}$ & 3.86 & Zhong et al. (2020) \\
\hline Pseudomonas sp. & Rice straw biomass of $0.5 \%$ in mineral salt medium & 1.75 & Qi et al. (2019) \\
\hline Bacillus velezensis & Palm oil mill effluent medium & 2.03 & Hassimi et al. (2020) \\
\hline Klebsiella oxytoca & $\begin{array}{l}\text { Acetonitrile } 1 \mathrm{~g} / \mathrm{L} \text {, glucose } 8 \mathrm{~g} / \mathrm{L}, \mathrm{Na}_{2} \mathrm{HPO}_{4} 50 \mathrm{mM}, \mathrm{KH}_{2} \mathrm{PO}_{4} 100 \mathrm{mM} \text {, } \\
\mathrm{MgSO}_{4} 1 \mathrm{mM}, \mathrm{CaCl}_{2} 0.1 \mathrm{mM}\end{array}$ & 4.60 & Fan et al. (2019) \\
\hline Sphingomonas yabuuchiae & $\begin{array}{l}\text { (g/L) Chromotropic acid wastewater, } \mathrm{K}_{2} \mathrm{HPO}_{4} 5, \mathrm{KH}_{2} \mathrm{PO}_{4} 2, \mathrm{MgSO}_{4} 0.2 \text {, } \\
\text { urea } 0.5 \text {, yeast extract } 0.5\end{array}$ & 9.71 & Zhong et al. (2014) \\
\hline Pseudomonas veronii & $\begin{array}{l}\text { ( } \mathrm{g} / \mathrm{L} \text { ) Peanut hull hydrolyzate yeast extract } 3, \mathrm{~K}_{2} \mathrm{HPO}_{4} 0.6, \mathrm{MgSO}_{4} \cdot 7 \mathrm{H}_{2} \mathrm{O} \\
0.1\end{array}$ & 3.39 & Liu et al. (2016b) \\
\hline Bacillus agaradhaerens & (g/L) Kitchen waste $40, \mathrm{Na}_{2} \mathrm{CO}_{3} 10$ & 6.92 & Liu et al. (2019) \\
\hline Bacillus agaradhaerens & (g/L) Rice bran 20 , yeast extract $3, \mathrm{Na}_{2} \mathrm{CO}_{3} 20$ & 12.94 & Liu et al. (2017a) \\
\hline Aspergillus flavus & Hydrolysate of chicken viscera & 6.00 & Mohammed and Dagang (2019a) \\
\hline Bacillus marisflavi NA8 & Enzymatic hydrolysate of palm oil mill effluent & 9.72 & Bukhari et al. (2020) \\
\hline Klebsiella pneumoniae & Starch processing industrial wastewater & 1.12 & Joshi et al. (2017) \\
\hline Paenibacillus polymyxa & $\begin{array}{l}\text { (g/L) Potato starch wastewater, } \mathrm{K}_{2} \mathrm{HPO}_{4} 4, \mathrm{KH}_{2} \mathrm{PO}_{4} 2, \mathrm{MgSO}_{4} 0.2, \mathrm{NaCl} \\
0.1 \text {, urea } 2.0\end{array}$ & 0.81 & Guo et al. (2015a) \\
\hline Enterobacter sp. & (g/L) Brewery wastewater (COD 1.48), glucose 8.94 & 1.27 & Ma et al. (2020) \\
\hline Cellulosimicrobium cellulans & $(\mathrm{g} / \mathrm{L})$ Dry corn stover of 20 , yeast extract of $3, \mathrm{Na}_{2} \mathrm{CO}_{3} 0.4$ & 4.75 & Liu et al. (2015d) \\
\hline Rhodococcus erythropolis & $\begin{array}{l}\text { (g/L) Potato starch wastewater, } \mathrm{K}_{2} \mathrm{HPO}_{4} 4, \mathrm{KH}_{2} \mathrm{PO}_{4} 2, \mathrm{MgSO}_{4} 0.2, \mathrm{NaCl} \\
0.1 \text {, urea } 2\end{array}$ & 0.97 & Guo et al. (2018b) \\
\hline Citrobacter sp. & (g/L) Wet biomass of Microcystis aeruginosa 10 and glucose 10 & 3.40 & Xu et al. (2017) \\
\hline Aspergillus niger & (g/L) Potato starch wastewater (COD 5.9), glucose 20, urea 0.2 & 0.82 & Pu et al. (2018) \\
\hline Klebsiella variicola & $\begin{array}{l}\text { (g/L) Corn ethanol wastewater, } \mathrm{K}_{2} \mathrm{HPO}_{4} 5, \mathrm{KH}_{2} \mathrm{PO}_{4} 2, \mathrm{MgSO}_{4} 0.2, \mathrm{NaCl} \\
0.1\end{array}$ & 3.08 & Xia et al. (2018) \\
\hline Rhodococcus sp. & Alkaline-thermal treated sludge $100 \mathrm{~g} / \mathrm{L}$ & 4.20 & Guo et al. (2013) \\
\hline Bacillus subtilis & $\begin{array}{l}\text { (g/L) Palm jaggery 20, yeast extract 2.5, } \mathrm{NH}_{4} \mathrm{NO}_{2} 1.0, \mathrm{MgCl}_{2} 0.2 \\
\mathrm{~K}_{2} \mathrm{HPO}_{4} 5, \mathrm{NaCl} 0.1\end{array}$ & 13.42 & Sathiyanarayanan et al. (2013) \\
\hline Rhizopus sp. & $(\mathrm{g} / \mathrm{L})$ Potato starch wastewater with $\mathrm{COD}$ of 1.6 , urea $0.3, \mathrm{KH}_{2} \mathrm{PO}_{4} 0.04$ & 0.69 & Pu et al. (2014) \\
\hline Aspergillus niger & $\begin{array}{l}\text { (g/L) Palm oil mill effluent of TOC } 10 ; \text { glutamic acid 7.92; } \mathrm{MgSO}_{4} 0.5 ; \\
\mathrm{KCl} 0.5 ; \mathrm{FeSO}_{4} 0.01 ; \mathrm{K}_{2} \mathrm{HPO}_{4} 1.0\end{array}$ & 2.73 & Aljuboori et al. (2014) \\
\hline Rhodococcus erythropolis & $\begin{array}{l}\text { Excess sludge from municipal wastewater treatment and livestock } \\
\text { wastewater }\end{array}$ & 1.60 & Peng et al. (2014) \\
\hline Schizophyllum commune & $\begin{array}{l}\text { ( } \mathrm{g} / \mathrm{L} \text { ) Hydrolysates of rice hulls supplemented with yeast extract } 3 \text {, } \\
\mathrm{KH}_{2} \mathrm{PO}_{4} 0.5, \mathrm{MgSO}_{4} \cdot 7 \mathrm{H}_{2} \mathrm{O} 0.25\end{array}$ & 1.30 & Shu and Hsu (2011) \\
\hline Ochrobactium ciceri & $\begin{array}{l}\text { (g/L) Corn stover hydrolysates, } \mathrm{K}_{2} \mathrm{HPO}_{4} 5, \mathrm{KH}_{2} \mathrm{PO}_{4} 2, \mathrm{MgSO}_{4} 0.2, \mathrm{NaCl} \\
0.1 \text {, urea } 0.5 \text {, yeast extract } 0.5\end{array}$ & 3.80 & Ma et al. (2020) \\
\hline $\begin{array}{l}\text { Enterococcus faecalis, Proteus } \\
\text { mirabilis, Lysini bacillus sp. }\end{array}$ & $\begin{array}{l}\text { Hydrolyzed wheat bran extract, hydrolyzed peanut hull extract and } \\
0.1 \% \mathrm{MgSO}_{4}\end{array}$ & 5.01 & Vimala et al. (2020) \\
\hline
\end{tabular}

$C O D$ chemical oxygen demand, TOC total organic carbon

of lignocellulose structure, and increase the specific surface area of enzymatic hydrolysis, thereby improving the conversion efficiency from agricultural waste into microbial flocculant, and the highest yield of $12.94 \mathrm{~g} / \mathrm{L}$ was achieved, which showed a flocculating rate of $91.05 \%$ to Chlorella minutissima (Liu et al. 2017a). Pseudomonas boreopolis G22 was found to be able to secrete xylanase and simultaneously produce microbial flocculant. Thus, $P$. 


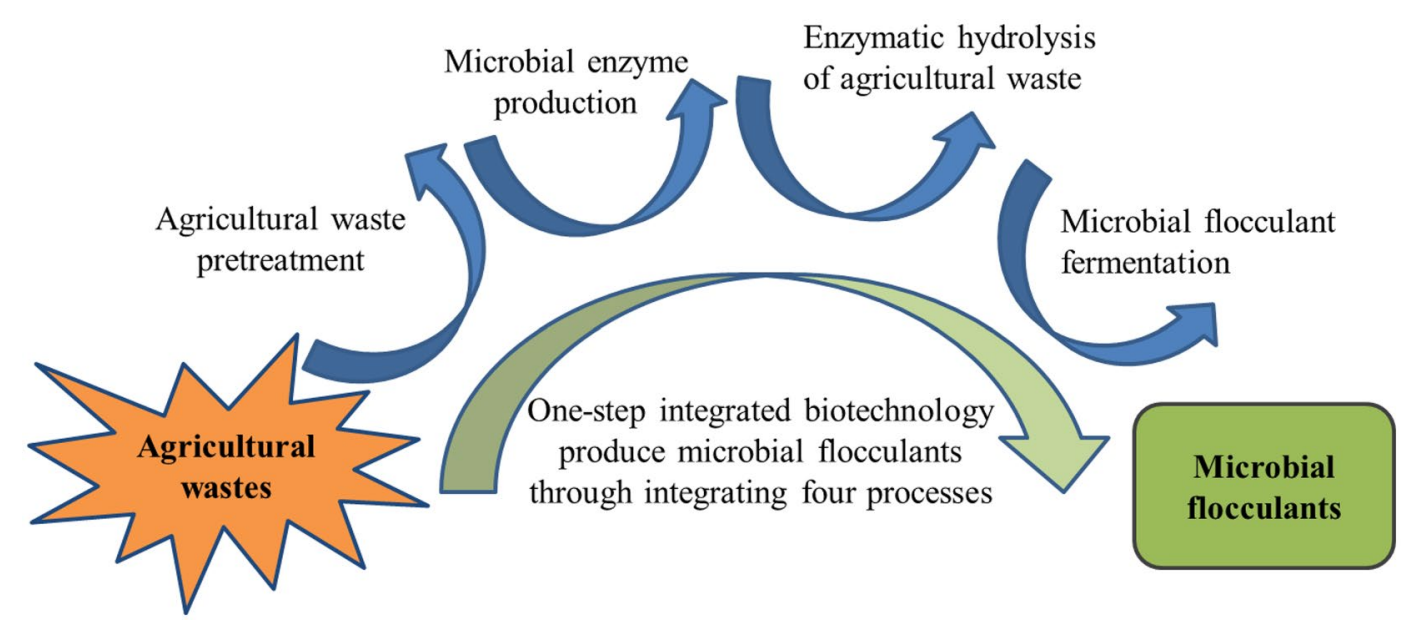

Fig. 1 Microbial flocculant produced by one-step integrated biotechnology

boreopolis $\mathrm{G} 22$ was used as a fermentation strain in onestep integrated biotechnology to convert grass lignocelluloses (agave, corn stover, Miscanthus, and wheat bran) into microbial flocculant. The yield reached $3.75 \mathrm{mg} / \mathrm{g}$ dry biomass, and the flocculation rate of obtained microbial flocculant to Scenedesmus abundans reached 95.7\% (Guo et al. 2018a, b).

At present, most of the studies are focused on the alternative carbon source, but few on the alternative nitrogen source. Feather is the solid waste of poultry processing plants (Kshetri et al. 2019). In addition to some fine feathers are used as filling materials of clothes, mattresses, and comforters, huge amount of feather wastes are discarded, causing environmental pollution, because feather waste is difficult to be degraded due to the strong hydrophobicity of keratin (Gao et al. 2014). Feather waste can be decomposed by keratinase producing strain and used as nitrogen source to produce microbial flocculants. B. agaradhaerens C9 is a bifunctional strain that can simultaneously produce keratinase and microbial flocculant. Therefore, $B$. agaradhaerens C9 can utilize feather waste as nitrogen source to produce microbial flocculant, which exhibited a good flocculating activity to straw ash-washing wastewater with low-density and high $\mathrm{pH}$ property, and the yield of $2.5 \mathrm{~g} / \mathrm{L}$ was obtained (Liu et al. 2020). In addition, kitchen waste is a semi-solid waste produced mainly by families, canteens and restaurants (Karthikeyan et al. 2018). It contains various organic substances such as starch, fat, protein, cellulose, pectin, and inorganic salt, which provide complete nutritional requirements for microorganisms to produce microbial flocculants. The strains that can directly convert kitchen waste into microbial flocculants generally need to produce a variety of degrading enzymes to decompose macromolecular substances in kitchen waste. B. agaradhaerens $\mathrm{C} 9$ was found to be able to produce multiple degradation enzymes including amylase, protease, lipase, cellulase, xylanase, and pectinase, achieving resourceful utilization of kitchen waste to produce microbial flocculants, which was successfully applied in the treatment of mining wastewater, and the yield reached $6.92 \mathrm{~g} / \mathrm{L}$ (Liu et al. 2019).

\section{Direct extraction from natural substances}

Biofilm is an aggregate of bacterial cells, which are encapsulated by self-secreted polysaccharides, proteins, and nucleic acids (Flemming et al. 2016). Some bacterial biofilms contain macromolecular substances with flocculation activity, so microbial flocculants can be extracted from some bacterial biofilms. For example, microbial flocculant was extracted from periphytic biofilm, and the yield reached $491.8 \mathrm{mg} / \mathrm{g}$ biofilm (Sun et al. 2018). Activated sludge contains a large amount of organic matters secreted by microorganisms in the process of wastewater treatment. It can be directly used as the fermentation medium for microbial flocculant production after heating pretreatment, alkali, or acid pretreatment (Guo et al. 2013, 2014). In addition, activated sludge is an aggregate composed of bacterial cells and extracellular polymeric substances, including polysaccharides and proteins produced by microbial metabolism, which has the potential to directly extract microbial flocculants. At present, microbial flocculants have been successfully extracted from activated sludge and applied in the wastewater treatment (Liu et al. 2009; Sun et al. 2012; Yan et al. 2020; Zhang et al. 2013), which not only reduces the production cost of microbial flocculants, but also realizes the resourceful utilization of activated sludge. 
However, the quality of extracted microbial flocculant is greatly affected by the source of activated sludge. Low purity limits its application in industrial fields with high safety requirement. Therefore, the microbial flocculants extracted from activated sludge are mainly used in fields with low purity requirement, such as wastewater treatment (Liu et al. 2009).

\section{Exploration of the extraction and preservation methods}

The cost of extraction and purification accounts for $30 \%-50 \%$ of the total production cost of microbial flocculants. Therefore, exploring efficient extraction methods or changing the application way is able to reduce the production cost of microbial flocculants. According to the purity requirement of microbial flocculants, the main extraction methods include organic reagent precipitation, gel adsorption, and high-performance liquid chromatography purification (Li et al. 2010; Sivasankar et al. 2020; Tang et al. 2014a), among which organic reagent precipitation is the most frequently used extraction method (Aljuboori et al. 2013; Chen et al. 2017b; Elkady et al. 2011; Li et al. 2013; Liu et al. 2015a, d, 2016b, 2020; Luvuyo et al. 2013; Manivasagan et al. 2015; Sekelwa et al. 2013; Subudhi et al. 2014; Sun et al. 2015b; Tang et al. 2014a, b; Wan et al. 2013; Wang et al. 2011; Xiong et al. 2010). Table 2 summarizes the extraction methods of some microbial flocculants. During the extraction process, microbial flocculant products generally lose 30-50\% flocculating activity (Liu et al. 2015a), and the extracted solid microbial flocculant needs to be dissolved in the solution before use to increase the dispersion of microbial flocculant in the solution and the contact probability with the suspended solid particles. Most of the microbial flocculants are macromolecular substances (Liu et al. 2015d), which are difficult to be dissolved, thereby increasing the operation difficulty. Therefore, under the premise of comprehensive consideration of transportation cost, it is also an ideal choice to directly use the liquid fermentation broth of microbial flocculants. Furthermore, improving the stability and prolonging the shelf life of microbial flocculant are also an effective strategy to reduce the application cost of microbial flocculants. However, a few studies on the stability of microbial flocculants were carried out. Previous study found that beta-glucosidase secreted by Bacillus licheniformis could degrade self-produced polysaccharide flocculant. Therefore, the deletion of beta-glucosidase synthesis gene improved the stability of microbial flocculant in fermentation broth of B. licheniformis (Chen et al. 2017c). The stability analysis of microbial flocculant in liquid fermentation broth produced from B. agaradhaerens $\mathrm{C} 9$ showed that its flocculating activity could maintain above $85 \%$ at $4{ }^{\circ} \mathrm{C}$ for more than 3 months (Liu et al. 2015a). In addition, correlation between composition of microbial flocculant and its thermal stability is listed in Table 4, suggesting that the thermal stability of polysaccharide flocculant is generally higher than that of protein flocculant, and the thermal stability of microbial flocculant depends on the relative contents of polysaccharide and protein (Chaisorn et al. 2016; Chen et al. 2017c). Therefore, to improve the stability of microbial flocculants and reduce its application cost, the strains that can produce microbial flocculant with high stability should be selected as industrial strains.

\section{Microbial flocculant production as an incidental product of other biological processes}

It is an effective strategy to reduce the production cost through producing microbial flocculant as an incidental product of other biological processes. Other microbial metabolites or other biological processes provide cost compensation for the production of microbial flocculants (Table 5). For examples, in the fermentation process of biological hydrogen production by Bacillus sp. XF-56 (Liu et al. 2015b), Pantoea agglomerans BH18 (Liu et al. 2016a) and Enterobacter aerogenes (Xu et al. 2018b), microbial flocculants are produced as an incidental product. The yield of microbial flocculant reached $3.6 \mathrm{~g} / \mathrm{L}$ during the hydrogen production by $E$. aerogenes (Xu et al. 2018b). Klebsiella oxytoca GS-4-08 produced 4.92-5.21 g/L microbial flocculant during the process of nitriles degradation (Yu et al. 2020a). And during the fermentation process for methane production by Methanosarcina spelaei RK-23, the flocculating activity of fermentation broth reached 95.6\% (Zhao et al. 2020).

\section{Combined use of traditional flocculant and microbial flocculant}

Combined use of microbial flocculants and traditional inorganic flocculants or organic polymeric flocculants is an useful way to reduce the application cost of microbial flocculants, because this method can play a synergistic role between them, which is conducive to reducing the consumption of microbial flocculants (Guo and Chen 2017b; Guo et al. 2015b; Huang et al. 2013; Li et al. 2014; Zhao et al. 2012). For examples, compared with microbial flocculants and aluminum sulfate alone, dual-coagulant of microbial flocculants and aluminum sulfate obviously improved the flocculating efficiency to Kaolin-humic acid solution (Bo et al. 2011). The combination of polysaccharide flocculant and poly-aluminum chloride significantly enhanced the removal efficiency of dissolved organic 
Table 5 Microbial flocculant production as an incidental product of other biological processes

\begin{tabular}{|c|c|c|c|}
\hline Strains & Bioprocesses & Yields or flocculating activity & Ref \\
\hline Enterobacter aerogenes & Biohydrogen production & $\begin{array}{l}\text { Bioflocculant yield } 3.6 \mathrm{~g} / \mathrm{L} \text { and biohydrogen } 35 \mathrm{~mL} \mathrm{H} / \mathrm{g} \text { dry weight algal } \\
\text { biomass }\end{array}$ & Xu et al. (2018b) \\
\hline Klebsiella oxytoca & Nitriles degradation & Bioflocculant yield was $4.92-5.21 \mathrm{~g} / \mathrm{L}$ & Yu et al. (2020a) \\
\hline Bacillus sp. & Production of hydrogen & 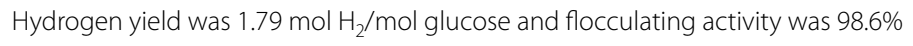 & Liu et al. (2015b) \\
\hline Pantoea agglomerans & Production of hydrogen & 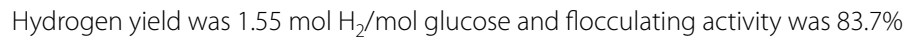 & Liu et al. (2016a) \\
\hline Methanosarcina spelaei & Methane production & $\begin{array}{l}\text { Methane yield was } 17.4 \mathrm{mmol} \text { methane/mol acetate and flocculating activity } \\
\text { was } 95.6 \%\end{array}$ & Zhao et al. (2020) \\
\hline
\end{tabular}

carbon in low-temperature drinking water and accelerate the growth rate of flocs (Huang et al. 2015b). The composite flocculant composed of microbial flocculant and aluminum salt showed a good application effect on synthetic dye wastewater, which can improve the floc size under acidic conditions and increase the formation speed of flocs under neutral or alkaline conditions (Huang et al. 2015a). After grafting with acrylamide chains, microbial flocculant produced by Bacillus pumilus JX860616 exhibited a good flocculating activity to domestic wastewater, the removal of chemical oxygen demand (COD), biochemical oxygen demand (BOD), total nitrogen, and total phosphorous reached $98 \%, 54 \%, 53 \%$, and 57\%, respectively (Ngema et al. 2020). When microbial flocculant produced by Paenibacillus polymyxa or conventional polyacrylamide was used independently to dewater the activated sludge, specific resistance to filtration (SRF) decreased by $65.5 \%$ and $71.7 \%$, and dry solids (DS) increased to 20.8 and $24.2 \%$, respectively. Interestingly, the sludge dewatering by the complex of microbial flocculant and polyacrylamide was improved with SRF decreased by $81.4 \%$ and DS increased to 28.4\% (Guo et al. 2015d). The composite of microbial flocculant and poly(acrylamide [2-(methacryloyloxy)ethyl]-trimethylammonium chloride) ( $\mathrm{P}(\mathrm{AM}-\mathrm{DMC})$ ) exhibited a good dewater ability to activated sludge, and DS and SRF appeared as $29.9 \%$ and $2.2 \times 10^{12} \mathrm{~m} / \mathrm{kg}$, which is significantly higher than DS $21.7 \%$ and SRF $3.6 \times 10^{12} \mathrm{~m} / \mathrm{kg}$ of sludge treated by microbial flocculant alone (Guo et al. 2015b). The harvesting efficiency of Chlorella regularis achieved a level of $96.77 \%$ with the combination use of microbial flocculant, $\mathrm{AlCl}_{3}$, and coagulant aid $\left(\mathrm{CaCl}_{2}\right)$, which is obviously better than the flocculation activity of microbial flocculant (52\%), Chemical Flocculant (49\%), and coagulant aid (66\%) alone (Zhang et al. 2016). In addition, the compound flocculant composed of microbial flocculant, aluminum sulfate, and poly-aluminum chloride can increase the treatment of synthetic dyeing wastewater (Huang et al. 2014).

\section{Microbial flocculant production promoted by inducer}

Some quorum-sensing signal molecules or chemical inducers can promote the fermentation production of microbial flocculants. It was found that the addition of quorum-sensing signal molecule $n$-hexanoyl-homoserine lactone (C6-HSL) into the fermentation medium of Agrobacterium tumefaciens strain F2 can promote the production of microbial flocculant. The yield of polysaccharide flocculant was enhanced by 1.75 times, and the flocculation activity was increased by $10 \%$ when the concentration of C6-HSL was $0.45 \mu \mathrm{M}$ (Huang et al. 2014). Furthermore, Agrobacterium tumefaciens F2 was found to be able to secrete $\mathrm{N}$-3-oxo-octanoyl-homoserine lactone (3-oxo-C8HSL), a microbial quorum-sensing signaling molecule of the $\mathrm{N}$-acyl-homoserine lactone (AHL) class. The addition of $0.22 \mu \mathrm{M}$ exogenous 3-oxo-C8HSL increased the production of exopolysaccharide flocculant by 1.55 times and the flocculation efficiency increased by $10.96 \%$ (Wu et al. 2015). In addition, a rotifer secretion produced from the species Philodina erythrophthalma was found to be able to significantly enhance the flocculability of Brevundimonas vesicularis LW13 and Bacillus cereus LW19, and promote the formation of microbial aggregation and floc (Ding et al. 2017).

\section{Perspectives in future research}

Develop microbial flocculants with wide application scope

At present, most of the reported microbial flocculants are only analyzed for the flocculating effect to 1-3 kinds of suspension sample, and the flocculation mechanism of different microbial flocculants is generally different when they flocculate the suspended solid particles (Table 3), mainly including charge neutralization, sweeping flocculation, and bridging flocculation. However, the existing research results indicate that most of the reported microbial flocculants are not able to flocculate all kinds of wastewater or cell suspension. Only a few microbial flocculants can simultaneously flocculate printing and dyeing wastewater, mining wastewater, and algae cell suspension. In general, the flocculation effect of microbial flocculants depends on different flocculation mechanisms and the surface charge, structural features, and particle 
size of suspended particles. The application scope of polysaccharide flocculant depending on metal ions is relatively wider, because the flocculation mechanism of polysaccharide flocculant is mostly metal ion-mediated bridging effect (Table 3), sometimes accompanied by charge neutralization effect, thus forming macromolecular bridging network to capture suspended particles (Xia et al. 2018). Therefore, in the future research, more attention should be paid to the screening of microbial flocculant producing bacteria with a wide application scope.

Construction of genetic engineering strains at genetic level Future research should focus on improving the production of microbial flocculant by constructing genetically engineered strains. Until now, only a few strains have been genetically modified, including Bacillus licheniformis CGMCC2876 (Chen et al. 2017b, c; Liu et al. 2017b) and Lipomyces starkeyi U9 (Yu et al. 2020b). This is mainly due to the complex structure and large molecular weight of microbial flocculants, which lead to the complex gene regulation of microbial flocculant synthesis. For example, in Bacillus subtilis, polysaccharides are synthesized and regulated by gene clusters composed of dozens of genes (Branda et al. 2005). Bacillus genus contains different species, most of which can synthesize macromolecular polysaccharides, but not all the polysaccharides synthesized by Bacillus have flocculating activity, indicating that the synthesis of microbial flocculant is very complex, which limits the construction of genetically engineered strain. Future research can focus on identifying functional genes through comparative genomics; for example, by comparing the gene clusters responsible for the synthesis of polysaccharides with and without flocculating activity, thereby identifying the functional genes regulating the synthesis of polysaccharide flocculants. In addition, it is also an ideal strategy for overexpression of key functional genes related to the synthesis of microbial flocculants, or deletion of functional genes that inhibit the synthesis of microbial flocculants and the genes related to microbial flocculant degrading enzyme. For example, in Bacillus subtilis 168, the core transcription factor SinR is a key inhibitor of polysaccharide synthesis gene cluster (Chu et al. 2006). By deleting $\sin R$ gene, the synthesis of polysaccharide can be significantly up-regulated.

\section{Obtain high-yield strains using genome shuffling}

To solve the problem of complex and unclear synthesis mechanism of microbial flocculants, genome shuffling is also a good choice for most microbial flocculant producing strains without mature genetic operation system
(Zhang et al. 2002). Genome shuffling can complete the recombination at different sites of the whole genome and integrate a variety of excellent phenotypes of the parent plants, which makes up for the defects of the classical physical and chemical mutation breeding to a large extent; the mutant used for genome reorganization comes from the same parent, which is easier to cross to form a stable phenotype; compared with genetic engineering breeding technology, genome shuffling technology does not need to know the whole-genome sequence data and metabolic regulatory network information. Therefore, in recent years, genome shuffling technology has been widely used to improve the yield of microbial metabolites or enhance the adaptability of microorganisms to adverse environment (Gong et al. 2009). Therefore, the microbial flocculant producing strain can be modified using genome shuffling in the future researches according to the technical process shown in Fig. 2.

\section{Combination use of bifunctional strains to convert organic wastes to microbial flocculants}

The bifunctional bacteria that simultaneously secrete degrading enzymes and produce microbial flocculants can directly convert macromolecular organic wastes into microbial flocculants without pretreatment process, such as using corn straw, corncob, or kitchen waste as the substrate of fermentation medium. However, the composition and structure of these macromolecular organic wastes are complex, and a variety of degradation enzymes are required to improve their degradation and conversion efficiency. It is difficult for single strain to provide a complete enzyme system. Therefore, it is also a good research direction to use multiple microbial flocculant producing bacteria that produce different degradation enzymes to synergistically utilize complex organic wastes, such as kitchen wastes and agricultural wastes.

\section{Exploration of cheap culture medium}

At present, the exploration of cheap carbon source has gained research progresses to some extent, but it is still lack of the search for cheap alternative nitrogen source and phosphorus source. Future studies should continue to explore cheap alternative fermentation medium to decrease the production cost of microbial flocculants.

\section{Scale-up fermentation and application process}

At present, most studies on microbial flocculant are at the laboratory level, and the large-scale fermentation production and application are still relatively lacking. Future research should focus on the parameter optimization during the process of technological scale-up test. 


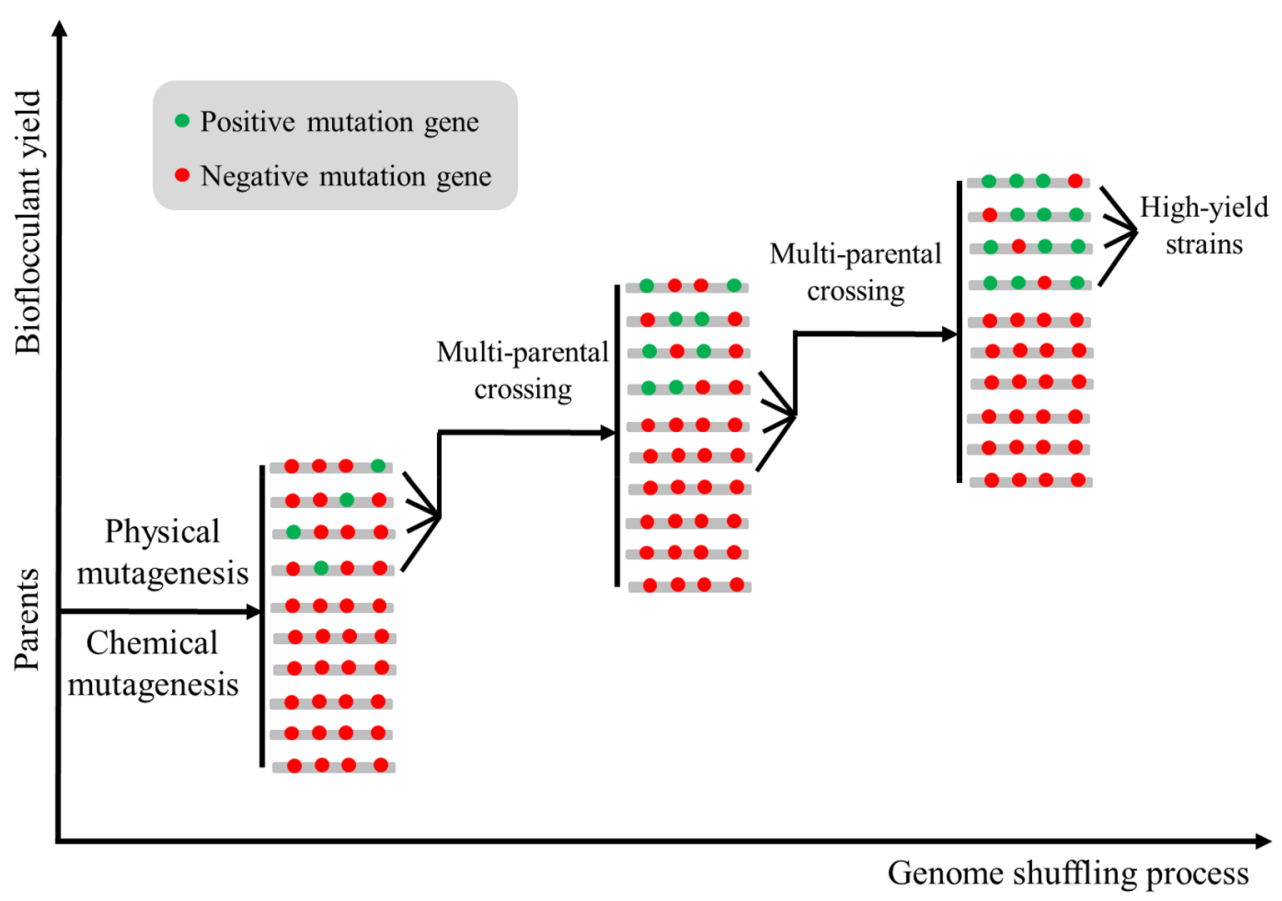

Fig. 2 Flowchart of microbial flocculant producing bacteria modified by genome shuffling

\section{Combined use of microbial flocculant with traditional flocculant or adsorbent}

Using traditional flocculants or adsorbents as flocculant aid can reduce the dosage of microbial flocculants and improve the flocculation efficiency. For example, the combined use of microbial flocculant and coal fly ash or activated carbon is able to play the adsorption role of fly ash and activated carbon to dye molecules in dyeing wastewater or metal ions in heavy metal wastewater. At the same time, with the help of microbial flocculants to accelerate flocculation sedimentation, the treatment efficiency of wastewater can be enhanced.

\section{Explore cheap extraction methods and improve the stability of microbial flocculants}

At present, the extraction of microbial flocculants is mainly achieved by organic reagent precipitation method, which accounts for more than $30 \%$ of the total production cost. Moreover, after extraction, the activity of microbial flocculant loses obviously. Therefore, future research needs to explore cheaper extraction methods. In addition, if liquid fermentation broth is directly used as liquid microbial flocculant, the extraction cost can be avoided. Future research should focus on improving the storage stability of liquid microbial flocculants, for example, by knocking out the microbial flocculants degrading enzyme gene in engineering strains, so as to improve the storage stability of liquid microbial flocculants.

\section{Conclusions}

Microbial flocculants will gradually replace inorganic flocculants and organic polymeric flocculants in more and more industrial fields due to the advantages of environmental friendly and efficient characteristics. Microbial flocculants have been successfully applied in the industrial fields with high safety requirement. However, the high production cost is still the main bottleneck problem that limits the large-scale production and application of microbial flocculants. The application scale and scope of microbial flocculants in the future depend on further reducing their production and application cost. In the future studies, the screening and construction of efficient functional strains, cheap culture medium, new fermentation production and application strategy, cheap extraction, and storage strategy are the key research directions.

\footnotetext{
Abbreviations

AHL: N-Acyl-homoserine lactone; AP: Acetone precipitate; BOD: Biological oxygen demand; COD: Chemical oxygen demand; CTAB-p: Cetyltrimethyl ammonium bromide precipitate; C6-HSL: N-Hexanoyl-homoserine lactone; 3-oxo-C8HSL: N-3-Oxo-octanoyl-homoserine lactone; DS: Dry solids; EP: Ethanol precipitate; FR: Flocculating rate; GFC: Gel filtration chromatography; IEC: Ion exchange chromatography; NA: Nucleic acid; Ps: Polysaccharide; Pr: Protein; P(AM-DMC): Poly(acrylamide [2-(methacryloyloxy)ethyl]-trimethylammonium chloride); SRF: Specific resistance to filtration; SS: Suspended solids; TOC: Total organic carbon; TSS: Total suspended solids; YE: Yeast extract.
}

Acknowledgements Not applicable. 


\section{Authors' contributions}

$\mathrm{CL}$ and DS: writing —original draft; $J$ and JZ: conceptualization and investigation; $C L$ and $W L$ : funding acquisition, and writing - review and editing. All authors read and approved the final manuscript.

\section{Funding}

This study is supported by National Natural Science Foundation of China (31970036, 31900401, and 31800020), Natural Science Foundation of the Jiangsu Higher Education Institutions of China (20KJB180001; 20KJA180007); Natural Science Foundation of Jiangsu Province (BK20181009), Natural Science Foundation of Xuzhou city (KC19196), Six Talent Peaks Project of Jiangsu Province (JNHB-103), and Qing Lan Project of Jiangsu Province, Priority Academic Program Development of Jiangsu Higher Education Institutions.

\section{Availability of data and materials}

Not applicable.

\section{Declarations}

Ethics approval and consent to participate

Not applicable.

\section{Consent for publication}

Not applicable.

\section{Competing interests}

The authors have declared that no conflicts of interest exist.

Received: 28 March 2021 Accepted: 8 June 2021

Published online: 14 June 2021

\section{References}

Abd El-Salam AE, Abd-El-Haleem D, Youssef AS, Zaki S, Abu-Elreesh G, El-Assar SA (2017) Isolation, characterization, optimization, immobilization and batch fermentation of bioflocculant produced by Bacillus aryabhattai strain PSK1. J Genet Eng Biotechnol 15(2):335-344. https://doi.org/10. 1016/j.jgeb.2017.07.002

Agunbiade MO, Van Heerden E, Pohl CH, Ashafa AT (2017) Flocculating performance of a bioflocculant produced by Arthrobacter humicola in sewage waste water treatment. BMC Biotechnol 17(1):1-9. https://doi.org/10. 1186/s12896-017-0375-0

Agunbiade MO, Pohl C, Heerden EV, Oyekola O, Ashafa A (2019) Evaluation of fresh water actinomycete bioflocculant and its biotechnological applications in wastewaters treatment and removal of heavy metals. Int J Environ Res Public Health 16(18):3337. https://doi.org/10.3390/ijerp h16183337

Aljuboori AHR, Idris A, Abdullah N, Mohamad R (2013) Production and characterization of a bioflocculant produced by Aspergillus flavus. Bioresour Technol 127:489-493. https://doi.org/10.1016/j.biortech.2012.09.016

Aljuboori AHR, Uemura Y, Osman NB, Yusup S (2014) Production of a bioflocculant from Aspergillus niger using palm oil mill effluent as carbon source. Bioresour Technol 171:66-70. https://doi.org/10.1016/j.biortech. 2014.08.038

Aljuboori AHR, Idris A, Al-Joubory HHR, Uemura Y, Abubakar BI (2015) Flocculation behavior and mechanism of bioflocculant produced by Aspergillus flavus. J Environ Manag 150:466-471. https://doi.org/10.1016/j.jenvm an.2014.12.035

Ayangbenro AS, Babalola OO, Aremu OS (2019) Bioflocculant production and heavy metal sorption by metal resistant bacterial isolates from gold mining soil. Chemosphere 231:113-120. https://doi.org/10.1016/j. chemosphere.2019.05.092

Bernaerts TM, Gheysen L, Kyomugasho C, Kermani ZJ, Vandionant S, Foubert I, Hendrickx ME, Van Loey AM (2018) Comparison of microalgal biomasses as functional food ingredients: focus on the composition of cell wall related polysaccharides. Algal Res 32:150-161. https://doi.org/10. 1016/j.algal.2018.03.017

Bisht V, Lal B (2019) Exploration of performance kinetics and mechanism of action of a potential novel bioflocculant BF-VB2 on clay and dye wastewater flocculation. Front Microbiol 10:1288. https://doi.org/10. 3389/fmicb.2019.01288

Bo X, Gao B, Peng N, Wang Y, Yue Q, Zhao Y (2011) Coagulation performance and floc properties of compound bioflocculant-aluminum sulfate dual-coagulant in treating kaolin-humic acid solution. Chem Eng J 173(2):400-406. https://doi.org/10.1016/j.cej.2011.07.077

Branda SS, Vik Å, Friedman L, Kolter R (2005) Biofilms: the matrix revisited. Trends Microbiol 13(1):20-26. https://doi.org/10.1016/j.tim.2004.11.006

Bukhari NA, Loh SK, Nasrin AB, Jahim JM (2020) Enzymatic hydrolysate of palm oil mill effluent as potential substrate for bioflocculant BM-8 production. Waste Biomass Valoriz 11(1):17-29. https://doi.org/10.1007/ s12649-018-0421-8

Campbell A (2002) The potential role of aluminium in Alzheimer's disease. Nephrol Dial Transplant 17(suppl_2):17-20. https://doi.org/10.1093/ ndt/17.suppl_2.17

Cao G, Zhang Y, Chen L, Liu J, Mao K, Li K, Zhou J (2015) Production of a bioflocculant from methanol wastewater and its application in arsenite removal. Chemosphere 141:274-281. https://doi.org/10.1016/j.chemo sphere.2015.08.009

Chaisorn W, Prasertsan P, Sompong O, Methacanon P (2016) Production and characterization of biopolymer as bioflocculant from thermotolerant Bacillus subtilis WD161 in palm oil mill effluent. Int J Hydrog Energy 41(46):21657-21664. https://doi.org/10.1016/j.ijhydene.2016.06.045

Chen H, Zhong C, Berkhouse H, Zhang Y, LV Y, Lu W, Yang Y, Zhou J (2016) Removal of cadmium by bioflocculant produced by Stenotrophomonas maltophilia using phenol-containing wastewater. Chemosphere 155:163-169. https://doi.org/10.1016/j.chemosphere.2016.04.044

Chen Z, Li Z, Liu P, Liu Y, Wang Y, Li Q, He N (2017a) Characterization of a novel bioflocculant from a marine bacterium and its application in dye wastewater treatment. BMC Biotechnol 17(1):1-11. https://doi.org/10. 1186/s12896-017-0404-z

Chen Z, Liu P, Li Z, Yu W, Wang Z, Yao H, Wang Y, Li Q, Deng X, He N (2017b) Identification of key genes involved in polysaccharide bioflocculant synthesis in Bacillus licheniformis. Biotechnol Bioeng 114(3):645-655 https://doi.org/10.1002/bit.26189

Chen Z, Meng T, Li Z, Liu P, Wang Y, He N, Liang D (2017c) Characterization of a beta-glucosidase from Bacillus licheniformis and its effect on bioflocculant degradation. AMB Express 7(1):1-7. https://doi.org/10.1186/ s13568-017-0501-3

Chu F, Kearns DB, Branda SS, Kolter R, Losick R (2006) Targets of the master regulator of biofilm formation in Bacillus subtilis. Mol Microbiol 59(4):1216-1228. https://doi.org/10.1111/j.1365-2958.2005.05019.x

Deng L, Guo W, Ngo HH, Zuthi MFR, Zhang J, Liang S, Li J, Wang J, Zhang $X$ (2015) Membrane fouling reduction and improvement of sludge characteristics by bioflocculant addition in submerged membrane bioreactor. Sep Purif Technol 156:450-458. https://doi.org/10.1016/j. seppur.2015.10.034

Ding G, Li X, Lin W, Kimochi Y, Sudo R (2017) Enhanced flocculation of two bioflocculation-producing bacteria by secretion of Philodina erythrophthalma. Water Res 112:208-216. https://doi.org/10.1016/j.watres.2017. 01.044

Dlamini NG, Basson AK, Pullabhotla VSR (2019) Optimization and application of bioflocculant passivated copper nanoparticles in the wastewater treatment. Int J Environ Res Public Health 16(12):2185. https://doi.org/ 10.3390/ijerph16122185

Dlamini NG, Basson AK, Pullabhotla VSR (2020) Biosynthesis of bioflocculant passivated copper nanoparticles, characterization and application. Phys Chem Earth 118:102898. https://doi.org/10.1016/j.pce.2020.102898

Elkady M, Farag S, Zaki S, Abu-Elreesh G, Abd-El-Haleem D (2011) Bacillus mojavensis strain 32A, a bioflocculant-producing bacterium isolated from an Egyptian salt production pond. Bioresour Technol 102(17):8143-8151. https://doi.org/10.1016/j.biortech.2011.05.090

Fan HC, Yu J, Chen RP, Yu L (2019) Preparation of a bioflocculant by using acetonitrile as sole nitrogen source and its application in heavy metals removal. J Hazard Mater 363:242-247. https://doi.org/10.1016/j.jhazm at.2018.09.063

Feng J, Yang Z, Zeng G, Huang J, Xu H, Zhang Y, Wei S, Wang L (2013) The adsorption behavior and mechanism investigation of $\mathrm{Pb}$ (II) removal by flocculation using microbial flocculant GA1. Bioresour Technol 148:414-421. https://doi.org/10.1016/j.biortech.2013.09.011 
Flemming HC, Wingender J, Szewzyk U, Steinberg P, Rice SA, Kjelleberg S (2016) Biofilms: an emergent form of bacterial life. Nat Rev Microbiol 14(9):563. https://doi.org/10.1038/nrmicro.2016.94

Gao L, Li R, Sui X, Li R, Chen C, Chen Q (2014) Conversion of chicken feather waste to $\mathrm{N}$-doped carbon nanotubes for the catalytic reduction of 4-nitrophenol. Environ Sci Technol 48(17):10191-10197. https://doi.org/ $10.1021 /$ es5021839

Giri SS, Harshiny M, Sen SS, Sukumaran V, Park SC (2015) Production and characterization of a thermostable bioflocculant from Bacillus subtilis F9, isolated from wastewater sludge. Ecotox Environ Safe 121:45-50. https://doi.org/10.1016/j.ecoenv.2015.06.010

Giri SS, Ryu E, Park SC (2019) Characterization of the antioxidant and antiinflammatory properties of a polysaccharide-based bioflocculant from Bacillus subtilis F9. Microb Pathog 136:103642. https://doi.org/10.1016/j. micpath.2019.103642

Gomaa EZ (2012) Production and characteristics of a heavy metals removing bioflocculant produced by Pseudomonas aeruginosa. Pol J Microbiol 61(4):281-289. https://doi.org/10.1159/000346669

Gong J, Zheng H, Wu Z, Chen T, Zhao X (2009) Genome shuffling: progress and applications for phenotype improvement. Biotechnol Adv 27(6):9961005. https://doi.org/10.1016/j.biotechadv.2009.05.016

Guo J (2015) Characteristics and mechanisms of Cu (II) sorption from aqueous solution by using bioflocculant MBFR10543. Appl Microbiol Biotechnol 99(1):229-240. https://doi.org/10.1007/s00253-014-6103-y

Guo J, Chen C (2017a) Removal of arsenite by a microbial bioflocculant produced from swine wastewater. Chemosphere 181:759-766. https://doi. org/10.1016/j.chemosphere.2017.04.119

Guo J, Chen C (2017b) Sludge conditioning using the composite of a bioflocculant and PAC for enhancement in dewaterability. Chemosphere 185:277-283. https://doi.org/10.1016/j.chemosphere.2017.06.111

Guo J, Ma J (2015) Bioflocculant from pre-treated sludge and its applications in sludge dewatering and swine wastewater pretreatment. Bioresour Technol 196:736-740. https://doi.org/10.1016/j.biortech.2015.07.113

Guo J, Yu J (2014) Sorption characteristics and mechanisms of Pb (II) from aqueous solution by using bioflocculant MBFR10543. App Microbiol Biotechnol 98(14):6431-6441. https://doi.org/10.1007/ s00253-014-5681-z

Guo J, Yang C, Zeng G (2013) Treatment of swine wastewater using chemically modified zeolite and bioflocculant from activated sludge. Bioresour Technol 143:289-297. https://doi.org/10.1016/j.biortech.2013.06.003

Guo J, Yang C, Peng L (2014) Preparation and characteristics of bacterial polymer using pre-treated sludge from swine wastewater treatment plant. Bioresour Technol 152:490-498. https://doi.org/10.1016/j.biort ech.2013.11.037

Guo J, Lau AK, Zhang Y, Zhao J (2015a) Characterization and flocculation mechanism of a bioflocculant from potato starch wastewater. Appl Microbiol Biotechnol 99(14):5855-5861. https://doi.org/10.1007/ s00253-015-6589-y

Guo J, Nengzi L, Zhao J, Zhang Y (2015b) Enhanced dewatering of sludge with the composite of bioflocculant MBFGA1 and P (AM-DMC) as a conditioner. Appl Microbiol Biotechnol 99(7):2989-2998. https://doi.org/10. 1007/s00253-015-6401-Z

Guo J, Yu J, Xin X, Zou C, Cheng Q, Yang H, Nengzi L (2015c) Characterization and flocculation mechanism of a bioflocculant from hydrolyzate of rice stover. Bioresour Technol 177:393-397. https://doi.org/10.1016/j.biort ech.2014.11.066

Guo J, Zhang Y, Zhao J, Zhang Y, Xiao X, Wang B, Shu B (2015d) Characterization of a bioflocculant from potato starch wastewater and its application in sludge dewatering. Appl Microbiol Biotechnol 99(13):54295437. https://doi.org/10.1007/s00253-015-6567-4

Guo H, Hong C, Zhang C, Zheng B, Jiang D, Qin W (2018a) Bioflocculants' production from a cellulase-free xylanase-producing Pseudomonas boreopolis $\mathrm{G} 22$ by degrading biomass and its application in cost-effective harvest of microalgae. Bioresour Technol 255:171-179. https://doi. org/10.1016/j.biortech.2018.01.082

Guo J, Liu J, Yang Y, Zhou Y, Jiang S, Chen C (2018b) Fermentation and kinetics characteristics of a bioflocculant from potato starch wastewater and its application. Sci Rep 8(1):1-11. https://doi.org/10.1038/ s41598-018-21796-X

Hassimi AH, Hafiz RE, Muhamad MH, Abdullah SRS (2020) Bioflocculant production using palm oil mill and sago mill effluent as a fermentation feedstock: characterization and mechanism of flocculation. J Environ Manag 260:110046. https://doi.org/10.1016/j.jenvman.2019.110046 Huang X, Gao B, Yue Q, Wang Y, Li Q, Zhao S, Sun S (2013) Effect of dosing sequence and raw water $\mathrm{pH}$ on coagulation performance and flocs properties using dual-coagulation of polyaluminum chloride and compound bioflocculant in low temperature surface water treatment. Chem Eng J 229:477-483. https://doi.org/10.1016/j.cej.2013.06.029

Huang X, Bo X, Zhao Y, Gao B, Wang Y, Sun S, Yue Q, Li Q (2014) Effects of compound bioflocculant on coagulation performance and floc properties for dye removal. Bioresour Technol 165:116-121. https://doi.org/10. 1016/j.biortech.2014.02.125

Huang X, Gao B, Yue Q, Zhang Y, Sun S (2015a) Compound bioflocculant used as a coagulation aid in synthetic dye wastewater treatment: the effect of solution pH. Sep Purif Technol 154:108-114. https://doi.org/10. 1016/j.seppur.2015.09.018

Huang X, Sun S, Gao B, Yue Q, Wang Y, Li Q (2015b) Coagulation behavior and floc properties of compound bioflocculant-polyaluminum chloride dual-coagulants and polymeric aluminum in low temperature surface water treatment. J Environ Sci 30:215-222. https://doi.org/10.1016/j.jes. 2014.07.033

Huang J, Huang ZL, Zhou JX, Li CZ, Yang ZH, Ruan M, Li H, Zhang X, Wu ZJ, Qin XL (2019) Enhancement of heavy metals removal by microbial flocculant produced by Paenibacillus polymyxa combined with an insufficient hydroxide precipitation. Chem Eng J 374:880-894. https://doi.org/10. 1016/j.cej.2019.06.009

Joshi N, Naresh Dholakiya R, Anil Kumar M, Mody KH (2017) Recycling of starch processing industrial wastewater as a sole nutrient source for the bioflocculant production. Environ Prog Sustain Energy 36(5):1458-1465 https://doi.org/10.1002/ep.12608

Kaarmukhilnilavan RS, Selvam A, Wong JW, Murugesan K (2020) $\mathrm{Ca}^{2+}$ dependent flocculation efficiency of avian egg protein revealed unique surface specific interaction with kaolin particles: a new perception in bioflocculant research. Colloids Surf A Physicochem Eng Asp 603:125177. https:// doi.org/10.1016/j.colsurfa.2020.125177

Kanmani P, Yuvapriya S (2018) Exopolysaccharide from Bacillus sp. YP03: its properties and application as a flocculating agent in wastewater treatment. Int J Environ Sci Technol 15(12):2551-2560. https://doi.org/10. 1007/s13762-017-1416-x

Karthikeyan OP, Trably E, Mehariya S, Bernet N, Wong JW, Carrere H (2018) Pretreatment of food waste for methane and hydrogen recovery: a review. Bioresour Technol 249:1025-1039. https://doi.org/10.1016/j. biortech.2017.09.105

Kshetri P, Roy SS, Sharma SK, Singh TS, Ansari MA, Prakash N, Ngachan S (2019) Transforming chicken feather waste into feather protein hydrolysate using a newly isolated multifaceted keratinolytic bacterium Chryseobacterium sediminis RCM-SSR-7. Waste Biomass Valoriz 10(1):1-11. https://doi.org/10.1007/s12649-017-0037-4

Lei X, Chen Y, Shao Z, Chen Z, Li Y, Zhu H, Zhang J, Zheng W, Zheng T (2015) Effective harvesting of the microalgae Chlorella vulgaris via flocculationflotation with bioflocculant. Bioresour Technol 198:922-925. https://doi. org/10.1016/j.biortech.2015.08.095

Li Q, Liu HL, Qi QS, Wang FS, Zhang YZ (2010) Isolation and characterization of temperature and alkaline stable bioflocculant from Agrobacterium sp. M-503. New Biotechnol 27(6):789-794. https://doi.org/10.1016/j.nbt. 2010.09 .002

Li O, Lu C, Liu A, Zhu L, Wang PM, Qian CD, Jiang XH, Wu XC (2013) Optimization and characterization of polysaccharide-based bioflocculant produced by Paenibacillus elgii B69 and its application in wastewater treatment. Bioresour Technol 134:87-93. https://doi.org/10.1016/j.biort ech.2013.02.013

Li R, Gao B, Huang X, Dong H, Li X, Yue Q, Wang Y, Li Q (2014) Compound bioflocculant and polyaluminum chloride in kaolin-humic acid coagulation: factors influencing coagulation performance and floc characteristics. Bioresour Technol 172:8-15. https://doi.org/10.1016/j. biortech.2014.08.126

Li L, Ma F, Zuo H (2016a) Production of a novel bioflocculant and its flocculation performance in aluminum removal. Bioengineered 7(2):98-105. https://doi.org/10.1080/21655979.2016.1164370

Li Y, Xu Y, Liu L, Jiang X, Zhang K, Zheng T, Wang H (2016b) First evidence of bioflocculant from Shinella albus with flocculation activity on 
harvesting of Chlorella vulgaris biomass. Bioresour Technol 218:807-815. https://doi.org/10.1016/j.biortech.2016.07.034

Li J, Yun YQ, Xing L, Song L (2017) Novel bioflocculant produced by salt-tolerant, alkaliphilic strain Oceanobacillus polygoni HG6 and its application in tannery wastewater treatment. Biosci Biotechnol Biochem 81(5):10181025. https://doi.org/10.1080/09168451.2016.1274635

Liu W, Yuan H, Yang J, Li B (2009) Characterization of bioflocculants from biologically aerated filter backwashed sludge and its application in dying wastewater treatment. Bioresour Technol 100(9):2629-2632. https://doi. org/10.1016/j.biortech.2008.12.017

Liu W, Wang K, Li B, Yuan H, Yang J (2010) Production and characterization of an intracellular bioflocculant by Chryseobacterium daeguense W6 cultured in low nutrition medium. Bioresour Technol 101(3):1044-1048. https://doi.org/10.1016/j.biortech.2009.08.108

Liu ZY, Hu ZQ, Wang T, Chen YY, Zhang J, Yu JR, Zhang T, Zhang YF, Li YL (2013) Production of novel microbial flocculants by Klebsiella sp. TG-1 using waste residue from the food industry and its use in defecating the trona suspension. Bioresour Technol 139:265-271. https://doi.org/10. 1016/j.biortech.2013.03.165

Liu J, Ma J, Liu Y, Yang Y, Yue D, Wang H (2014) Optimized production of a novel bioflocculant M-C11 by Klebsiella sp. and its application in sludge dewatering. J Environ Sci 26(10):2076-2083. https://doi.org/10.1016/j. jes.2014.08.007

Liu C, Wang K, Jiang JH, Liu WJ, Wang JY (2015a) A novel bioflocculant produced by a salt-tolerant, alkaliphilic and biofilm-forming strain Bacillus agaradhaerens $\mathrm{C} 9$ and its application in harvesting Chlorella minutissima UTEX2341. Biochem Eng J 93:166-172. https://doi.org/10.1016/j. bej.2014.10.006

Liu H, Chen G, Wang G (2015b) Characteristics for production of hydrogen and bioflocculant by Bacillus sp. XF-56 from marine intertidal sludge. Int J Hydrog Energy 40(3):1414-1419. https://doi.org/10.1016/j.jihydene. 2014.11.110

Liu W, Liu C, Yuan H, Yang J (2015c) The mechanism of kaolin clay flocculation by a cation-independent bioflocculant produced by Chryseobacterium daeguense W6. AlMS Environ Sci 2(2):169-179. https://doi.org/10.3934/ environsci.2015.2.169

Liu W, Zhao C, Jiang J, Lu Q, Hao Y, Wang L, Liu C (2015d) Bioflocculant production from untreated corn stover using Cellulosimicrobium cellulans L804 isolate and its application to harvesting microalgae. Biotechnol Biofuels 8(1):1-12. https://doi.org/10.1186/s13068-015-0354-4

Liu H, Wang H, Qin H (2016a) Characteristics of hydrogen and bioflocculant production by a transposon-mutagenized strain of Pantoea agglomerans BH18. Int J Hydrog Energy 41(48):22786-22792. https://doi.org/10. 1016/j.ijhydene.2016.10.091

Liu W, Hao Y, Jiang J, Zhu A, Zhu J, Dong Z (2016b) Production of a bioflocculant from Pseudomonas veronii L918 using the hydrolyzate of peanut hull and its application in the treatment of ash-flushing wastewater generated from coal fired power plant. Bioresour Technol 218:318-325. https://doi.org/10.1016/j.biortech.2016.06.108

Liu C, Hao Y, Jiang J, Liu W (2017a) Valorization of untreated rice bran towards bioflocculant using a lignocellulose-degrading strain and its use in microalgal biomass harvest. Biotechnol Biofuels 10(1):1-12. https://doi. org/10.1186/s13068-017-0780-6

Liu P, Chen Z, Yang L, Li Q, He N (2017b) Increasing the bioflocculant production and identifying the effect of overexpressing eps $B$ on the synthesis of polysaccharide and Y-PGA in Bacillus licheniformis. Microb Cell Fact 16(1):1-10. https://doi.org/10.1186/s12934-017-0775-9

Liu W, Dong Z, Sun D, Chen Y, Wang S, Zhu J, Liu C (2019) Bioconversion of kitchen wastes into bioflocculant and its pilot-scale application in treating iron mineral processing wastewater. Bioresour Technol 288:121505. https://doi.org/10.1016/j.biortech.2019.121505

Liu W, Dong Z, Sun D, Dong Q, Wang S, Zhu J, Liu C (2020) Production of bioflocculant using feather waste as nitrogen source and its use in recycling of straw ash-washing wastewater with low-density and high $\mathrm{pH}$ property. Chemosphere 252:126495. https://doi.org/10.1016/j.chemo sphere.2020.126495

Luo Z, Chen L, Chen C, Zhang W, Liu M, Han Y, Zhou J (2014) Production and characteristics of a bioflocculant by Klebsiella pneumoniae YZ-6 isolated from human saliva. Appl Biochem Biotechnol 172(3):1282-1292. https://doi.org/10.1007/s12010-013-0601-8
Luo L, Zhao Z, Huang X, Du X, Wang CA, Li J, Wang L, Xu Q (2016) Isolation, identification, and optimization of culture conditions of a bioflocculantproducing bacterium Bacillus megaterium SP1 and its application in aquaculture wastewater treatment. BioMed Res Int 2016:2758168. https://doi.org/10.1155/2016/2758168

Luvuyo N, Nwodo UU, Mabinya LV, Okoh Al (2013) Studies on bioflocculant production by a mixed culture of Methylobacterium sp. Obi and Actinobacterium sp. Mayor. BMC Biotechnol 13(1):1-7. https://doi.org/10. 1186/1472-6750-13-62

Ma L, Liang J, Liu Y, Zhang Y, Ma P, Pan Z, Jiang W (2020) Production of a bioflocculant from Enterobacter sp. P3 using brewery wastewater as substrate and its application in fracturing flowback water treatment. Environ Sci Pollut Res 27(15):18242-18253. https://doi.org/10.1007/ s11356-020-08245-x

Makapela B, Okaiyeto K, Ntozonke N, Nwodo UU, Green E, Mabinya LV, Okoh A (2016) Assessment of Bacillus pumilus isolated from fresh water milieu for bioflocculant production. Appl Sci 6(8):211. https://doi.org/10.3390/ app6080211

Maliehe T, Simonis J, Basson A, Reve M, Ngema S, Xaba P (2016) Production, characterisation and flocculation mechanism of bioflocculant TMT-1 from marine Bacillus pumilus JX860616. Afr J Biotechnol 15(41):23522367. https://doi.org/10.5897/AJB2016.15614

Maliehe TS, Basson AK, Dlamini NG (2019) Removal of pollutants in mine wastewater by a non-cytotoxic polymeric bioflocculant from Alcaligenes faecalis HCB2. Int J Environ Res Public Health 16(20):4001. https:// doi.org/10.3390/ijerph16204001

Manivasagan P, Kang KH, Kim DG, Kim SK (2015) Production of polysaccharidebased bioflocculant for the synthesis of silver nanoparticles by Streptomyces sp. Int J Biol Macromol 77:159-167. https://doi.org/10.1016/j.jibio mac.2015.03.022

Markou G, Nerantzis E (2013) Microalgae for high-value compounds and biofuels production: a review with focus on cultivation under stress conditions. Biotechnol Adv 31(8):1532-1542. https://doi.org/10.1016/j. biotechadv.2013.07.011

Mohammed JN, Dagang WRZW (2019a) Culture optimization for production and characterization of bioflocculant by Aspergillus flavus grown on chicken viscera hydrolysate. World J Microbiol Biotechnol 35(8):1-19. https://doi.org/10.1007/s11274-019-2696-8

Mohammed JN, Dagang WRZW (2019b) Role of cationization in bioflocculant efficiency: a review. Environ Process 6(2):355-376. https://doi.org/10. 1007/s40710-019-00372-z

Monlau F, Sambusiti C, Barakat A, Quéméneur M, Trably E, Steyer JP, Carrère H (2014) Do furanic and phenolic compounds of lignocellulosic and algae biomass hydrolyzate inhibit anaerobic mixed cultures? A Comprehensive Review. Biotechnol Adv 32(5):934-951. https://doi.org/10.1016/j. biotechadv.2014.04.007

Mu J, Zhou H, Chen Y, Yang G, Cui X (2018) Revealing a novel natural bioflocculant resource from Ruditapes philippinarum: effective polysaccharides and synergistic flocculation. Carbohydr Polym 186:17-24. https://doi. org/10.1016/j.carbpol.2018.01.036

Mu J, Wang D, Yang G, Cui X, Yang Q (2019) Preparation and characterization of a substitute for Ruditapes philippinarum conglutination mud as a natural bioflocculant. Bioresour Technol 281:480-484. https://doi.org/ 10.1016/j.biortech.2019.02.080

Mussatto SI, Roberto IC (2004) Alternatives for detoxification of diluted-acid lignocellulosic hydrolyzates for use in fermentative processes: a review. Bioresour Technol 93(1):1-10. https://doi.org/10.1016/j.biortech.2003. 10.005

Muthulakshmi L, Rajini N, Rajalu AV, Siengchin S, Kathiresan T (2017) Synthesis and characterization of cellulose/silver nanocomposites from bioflocculant reducing agent. Int J Biol Macromol 103:1113-1120. https://doi. org/10.1016/j.jijbiomac.2017.05.068

Muthulakshmi L, Rajalu AV, Kaliaraj GS, Siengchin S, Parameswaranpillai J, Saraswathi R (2019) Preparation of cellulose/copper nanoparticles bionanocomposite films using a bioflocculant polymer as reducing agent for antibacterial and anticorrosion applications. Compos B Eng 175:107177. https://doi.org/10.1016/j.compositesb.2019.107177

Ndikubwimana T, Zeng X, Liu Y, Chang JS, Lu Y (2014) Harvesting of microalgae Desmodesmus sp. $F 51$ by bioflocculation with bacterial bioflocculant. Algal Res 6:186-193. https://doi.org/10.1016/.algal.2014.09.004 
Ndikubwimana T, Zeng X, Murwanashyaka T, Manirafasha E, He N, Shao W, Lu Y (2016) Harvesting of freshwater microalgae with microbial bioflocculant: a pilot-scale study. Biotechnol Biofuels 9(1):1-11. https://doi.org/ 10.1186/s13068-016-0458-5

Ngema S, Basson A, Maliehe T (2020) Synthesis, characterization and application of polyacrylamide grafted bioflocculant. Phys Chem Earth 115:102821. https://doi.org/10.1016/j.pce.2019.102821

Nie M, Yin X, Jia J, Wang Y, Liu S, Shen Q, Li P, Wang Z (2011) Production of a novel bioflocculant MNXY1 by Klebsiella pneumoniae strain NY1 and application in precipitation of cyanobacteria and municipal wastewater treatment. J Appl Microbiol 111(3):547-558. https://doi.org/10.1111/j. 1365-2672.2011.05080.x

Nwodo UU, Green E, Mabinya LV, Okaiyeto K, Rumbold K, Obi LC, Okoh Al (2014) Bioflocculant production by a consortium of Streptomyces and Cellulomonas species and media optimization via surface response model. Colloids Surf B Biointerfaces 116:257-264. https://doi.org/10. 1016/j.colsurfb.2014.01.008

Okaiyeto K, Nwodo UU, Mabinya LV, Okoh Al (2015a) Bacillus toyonensis strain AEMREG6, a bacterium isolated from South African marine environment sediment samples produces a glycoprotein bioflocculant. Molecules 20(3):5239-5259. https://doi.org/10.3390/molecules20035239

Okaiyeto K, Nwodo UU, Mabinya LV, Okoli AS, Okoh Al (2015b) Characterization of a bioflocculant (MBF-UFH) produced by Bacillus sp. AEMREG7. Int J Mol Sci 16(6):12986-13003. https://doi.org/10.3390/ijms160612986

Okaiyeto K, Nwodo UU, Okoli SA, Mabinya LV, Okoh Al (2016) Implications for public health demands alternatives to inorganic and synthetic flocculants: bioflocculants as important candidates. MicrobiologyOpen 5(2):177-211. https://doi.org/10.1002/mbo3.334

Pathak M, Sarma HK, Bhattacharyya KG, Subudhi S, Bisht V, Lal B, Devi A (2017) Characterization of a novel polymeric bioflocculant produced from bacterial utilization of $n$-hexadecane and its application in removal of heavy metals. Front Microbiol 8:170. https://doi.org/10.3389/fmicb. 2017.00170

Peng L, Yang C, Zeng G, Wang L, Dai C, Long Z, Liu H, Zhong Y (2014) Characterization and application of bioflocculant prepared by Rhodococcus erythropolis using sludge and livestock wastewater as cheap culture media. Appl Microbiol Biotechnol 98(15):6847-6858. https://doi.org/10. 1007/s00253-014-5725-4

Pu SY, Qin LL, Che JP, Zhang BR, Xu M (2014) Preparation and application of a novel bioflocculant by two strains of Rhizopus sp. using potato starch wastewater as nutrilite. Bioresour Technol 162:184-191. https://doi.org/ 10.1016/j.biortech.2014.03.124

Pu S, Ma H, Deng D, Xue S, Zhu R, Zhou Y, Xiong X (2018) Isolation, identification, and characterization of an Aspergillus niger bioflocculantproducing strain using potato starch wastewater as nutrilite and its application. PLoS ONE 13(1):e0190236. https://doi.org/10.1371/journal. pone.0190236

Pu L, Zeng YJ, Xu P, Li FZ, Zong MH, Yang JG, Lou WY (2020) Using a novel polysaccharide BM2 produced by Bacillus megaterium strain PL8 as an efficient bioflocculant for wastewater treatment. Int J Biol Macromol 162:374-384. https://doi.org/10.1016/j.ijbiomac.2020.06.167

Qi Z, Zhu Y, Guo H, Chen Y, Zhao Y, Zhou Y, Wang X, Yang Y, Qin W, Shao Q (2019) Production of glycoprotein bioflocculant from untreated rice straw by a CAZyme-rich bacterium, Pseudomonas sp. HP2. J Biotechnol 306:185-192. https://doi.org/10.1016/j.jbiotec.2019.10.011

Qiao N, Gao M, Zhang X, Du Y, Fan X, Wang L, Liu N, Yu D (2019) Trichosporon fermentans biomass flocculation from soybean oil refinery wastewater using bioflocculant produced from Paecilomyces sp. M2-1. Appl Microbiol Biotechnol 103(6):2821-2831. https://doi.org/10.1007/ s00253-019-09643-z

Rasulov BA, Pattaeva MA, Yili A, Aisa HA (2016a) Polysaccharide-based bioflocculant template of a diazotrophic Bradyrhizobium japonicum 36 for controlled assembly of AgCl nanoparticles. Int J Biol Macromol 89:682-688. https://doi.org/10.1016/j.ijbiomac.2016.03.067

Rasulov BA, Rozi P, Pattaeva MA, Yili A, Aisa HA (2016b) Exopolysaccharidebased bioflocculant matrix of Azotobacter chroococcum XU1 for synthesis of $\mathrm{AgCl}$ nanoparticles and its application as a novel biocidal nanobiomaterial. Materials 9(7):528. https://doi.org/10.3390/ma907 0528

Roy M, Mohanty K (2020) Valorization of waste eggshell-derived bioflocculant for harvesting T. obliquus: process optimization, kinetic studies and recyclability of the spent medium for circular bioeconomy. Bioresour Technol 307:123205. https://doi.org/10.1016/j.biortech.2020.123205

Sajayan A, Kiran GS, Priyadharshini S, Poulose N, Selvin J (2017) Revealing the ability of a novel polysaccharide bioflocculant in bioremediation of heavy metals sensed in a Vibrio bioluminescence reporter assay. Environ Pollut 228:118-127. https://doi.org/10.1016/j.envpol.2017.05.020

Salehizadeh H, Shojaosadati S (2001) Extracellular biopolymeric flocculants: recent trends and biotechnological importance. Biotechnol Adv 19(5):371-385. https://doi.org/10.1016/s0734-9750(01)00071-4

Salehizadeh H, Yan N (2014) Recent advances in extracellular biopolymer flocculants. Biotechnol Adv 32(8):1506-1522. https://doi.org/10.1016/j. biotechadv.2014.10.004

Salehizadeh H, Yan N, Farnood R (2018) Recent advances in polysaccharide bio-based flocculants. Biotechnol Adv 36(1):92-119. https://doi.org/10. 1016/j.biotechadv.2017.10.002

Sarang M, Nerurkar A (2020) Amyloid protein produced by B. cereus CR4 possesses bioflocculant activity and has potential application in microalgae harvest. Biotechnol Lett 42(1):79-91. https://doi.org/10.1007/ s10529-019-02758-3

Sathiyanarayanan G, Kiran GS, Selvin J (2013) Synthesis of silver nanoparticles by polysaccharide bioflocculant produced from marine Bacillus subtilis MSBN17. Colloids Surf B Biointerfaces 102:13-20. https://doi.org/10. 1016/j.colsurfb.2012.07.032

Sekelwa C, Anthony UM, Vuyani ML, Anthony OI (2013) Characterization of a thermostable polysaccharide bioflocculant produced by Virgibacillus species isolated from Algoa bay. Afr J Microbiol Res 7(23):2925-2938. https://doi.org/10.5897/AJMR12.2371

Shahadat M, Teng TT, Rafatullah M, Shaikh Z, Sreekrishnan T, Ali SW (2017) Bacterial bioflocculants: a review of recent advances and perspectives. Chem Eng J 328:1139-1152. https://doi.org/10.1016/j.cej.2017.07.105

Shu CH, Hsu HJ (2011) Production of schizophyllan glucan by Schizophyllum commune ATCC 38548 from detoxificated hydrolysate of rice hull. J Taiwan Inst Chem Eng 42(3):387-393. https://doi.org/10.1016/j.jtice. 2010.08.009

Sivasankar P, Poongodi S, Lobo AO, Pugazhendhi A (2020) Characterization of a novel polymeric bioflocculant from marine actinobacterium Streptomyces sp. and its application in recovery of microalgae. Int Biodeter Biodegr 148:104883. https://doi.org/10.1016/j.ibiod.2020.104883

Subudhi S, Batta N, Pathak M, Bisht V, Devi A, Lal B (2014) Bioflocculant production and biosorption of zinc and lead by a novel bacterial species, Achromobacter sp. TERI-IASST N, isolated from oil refinery waste. Chemosphere 113:116-124. https://doi.org/10.1016/j.chemosphere. 2014.04.050

Subudhi S, Bisht V, Batta N, Pathak M, Devi A, Lal B (2016) Purification and characterization of exopolysaccharide bioflocculant produced by heavy metal resistant Achromobacter xylosoxidans. Carbohydr Polym 137:441-451. https://doi.org/10.1016/j.carbpol.2015.10.066

Sun J, Zhang X, Miao X, Zhou J (2012) Preparation and characteristics of bioflocculants from excess biological sludge. Bioresour Technol 126:362-366. https://doi.org/10.1016/j.biortech.2012.08.042

Sun PF, Lin H, Wang G, Lu LL, Zhao YH (2015a) Preparation of a new-style composite containing a key bioflocculant produced by Pseudomonas aeruginosa ZJU1 and its flocculating effect on harmful algal blooms. J Hazard Mater 284:215-221. https://doi.org/10.1016/j.jhazmat.2014.11. 025

Sun P, Hui C, Bai N, Yang S, Wan L, Zhang Q, Zhao Y (2015b) Revealing the characteristics of a novel bioflocculant and its flocculation performance in Microcystis aeruginosa removal. Sci Rep 5(1):1-12. https://doi.org/10. 1038/srep17465

Sun P, Zhang J, Esquivel-Elizondo S, Ma L, Wu Y (2018) Uncovering the flocculating potential of extracellular polymeric substances produced by periphytic biofilms. Bioresour Technol 248:56-60. https://doi.org/10. 1016/j.biortech.2017.06.103

Tang J, Qi S, Li Z, An Q, Xie M, Yang B, Wang Y (2014a) Production, purification and application of polysaccharide-based bioflocculant by Paenibacillus mucilaginosus. Carbohydr Polym 113:463-470. https://doi.org/10. 1016/j.carbpol.2014.07.045

Tang W, Song L, Li D, Qiao J, Zhao T, Zhao H (2014b) Production, characterization, and flocculation mechanism of cation independent, $\mathrm{pH}$ tolerant, and thermally stable bioflocculant from Enterobacter sp. ETH-2. PLoS ONE 9(12):e114591. https://doi.org/10.1371/journal.pone.0114591 
Tawila ZMA, Ismail S, Amr SSA, Abou Elkhair EK (2019) A novel efficient bioflocculant QZ-7 for the removal of heavy metals from industrial wastewater. RSC Adv 9(48):27825-27834. https://doi.org/10.1039/c9ra04683f

Tiwari ON, Khangembam R, Shamjetshabam M, Sharma AS, Oinam G, Brand JJ (2015) Characterization and optimization of bioflocculant exopolysaccharide production by Cyanobacteria Nostoc sp. BTA97 and Anabaena sp. BTA990 in culture conditions. Appl Biochem Biotechnol 176(7):1950-1963. https://doi.org/10.1007/s12010-015-1691-2

Vimala R, Escaline JL, Sivaramakrishnan S (2020) Characterization of selfassembled bioflocculant from the microbial consortium and its applications. J Environ Manag 258:110000. https://doi.org/10.1016/j.jenvman. 2019.110000

Wan C, Zhao XQ, Guo SL, Alam MA, Bai FW (2013) Bioflocculant production from Solibacillus silvestris W01 and its application in cost-effective harvest of marine microalga Nannochloropsis oceanica by flocculation. Bioresour Technol 135:207-212. https://doi.org/10.1016/j.biortech.2012. 10.004

Wang ZR, Sheng JP, Tian XL, WU TT, Liu WZ, Shen L (2011) Optimization of the production of exopolysaccharides by Bacillus thuringiensis 27 in sand biological soil crusts and its bioflocculant activity. Afr J Microbial Res 5(16):2359-2366

Wang L, Ma F, Lee DJ, Wang A, Ren N (2013) Bioflocculants from hydrolysates of corn stover using isolated strain Ochrobactium ciceri W2. Bioresour Technol 145:259-263. https://doi.org/10.1016/j.biortech.2012.11.020

Wang L, Lee DJ, Ma F, Wang A, Ren N (2014) Bioflocculants from isolated strain or mixed culture: role of phosphate salts and $\mathrm{Ca}^{2+}$ ions. J Taiwan Inst Chem Eng 45(2):527-532. https://doi.org/10.1016/j.jtice.2013.05.001

Wang Y, Yang Y, Ma F, Xuan L, Xu Y, Huo H, Zhou D, Dong S (2015) Optimization of Chlorella vulgaris and bioflocculant-producing bacteria co-culture: enhancing microalgae harvesting and lipid content. Lett Appl Microbiol 60(5):497-503. https://doi.org/10.1111/lam.12403

Wang T, Tang X, Zhang S, Zheng J, Zheng H, Fang L (2020) Roles of functional microbial flocculant in dyeing wastewater treatment: bridging and adsorption. J Hazard Mater 384:121506. https://doi.org/10.1016/j.jhazm at.2019.121506

Wu D, Li A, Yang J, Ma F, Chen H, Pi S, Wei W (2015) N-3-Oxo-octanoylhomoserine lactone as a promotor to improve the microbial flocculant production by an exopolysaccharide bioflocculant-producing bacterium Agrobacterium tumefaciens F2. RSC Adv 5(109):89531-89538. https://doi.org/10.1039/c5ra15657b

Xia X, Liang Y, Lan S, Li X, Xie Y, Yuan W (2018) Production and flocculating properties of a compound biopolymer flocculant from corn ethanol wastewater. Bioresour Technol 247:924-929. https://doi.org/10.1016/j. biortech.2017.10.003

Xing J, Yang JX, Li A, Ma F, Liu KX, Wu D, Wei W (2013) Removal efficiency and mechanism of sulfamethoxazole in aqueous solution by bioflocculant MFX. J Anal Methods Chem 2013:568614. https://doi.org/10.1155/ 2013/568614

Xiong Y, Wang Y, Yu Y, Li Q, Wang H, Chen R, He N (2010) Production and characterization of a novel bioflocculant from Bacillus licheniformis. Appl Environ Microbiol 76(9):2778-2782. https://doi.org/10.1128/AEM. 02558-09

Xu L, Huo M, Sun C, Cui X, Zhou D, Crittenden JC, Yang W (2017) Bioresources inner-recycling between bioflocculation of Microcystis aeruginosa and its reutilization as a substrate for bioflocculant production. Sci Rep 7(1):1-9. https://doi.org/10.1038/srep43784

Xu L, Ma R, Sun C, Sun D (2018a) Enterococcus faecalis bioflocculant enhances recovery of graphene oxide from water. Pol J Environ Stud 27(6):28112820. https://doi.org/10.15244/pjoes/81267

Xu L, Zhou M, Ju H, Zhang Z, Zhang J, Sun C (2018b) Enterobacter aerogenes metabolites enhance Microcystis aeruginosa biomass recovery for sustainable bioflocculant and biohydrogen production. Sci Total Environ 634:488-496. https://doi.org/10.1016/j.scitotenv.2018.03.327

Yan Z, Peng L, Deng M, Lin J (2020) Production of a bioflocculant by using activated sludge and its application in $\mathrm{Pb}$ (II) removal from aqueous solution. Open Chem 18(1):333-338. https://doi.org/10.1515/ chem-2020-0024

Yang Y, Ren N, Xue J, Yang J, Rong B (2007) Mutation effect of MeV protons on bioflocculant bacteria Bacillus cereus. Nucl Instrum Methods B 262(2):220-224. https://doi.org/10.1016/j.nimb.2007.05.016
Yang Q, Luo K, Liao DX, Li XM, Wang DB, Liu X, Zeng GM, Li X (2012) A novel bioflocculant produced by Klebsiella sp. and its application to sludge dewatering. Water Environ J 26(4):560-566. https://doi.org/10.1111/j. 1747-6593.2012.00319.x

Yang Z, Wang W, Liu S (2017) Flocculation of coal waste slurry using bioflocculant produced by Azotobacter chroococcum. Energy Fuel 31(2):14601467. https://doi.org/10.1021/acs.energyfuels.6b03052

Yellapu SK, Klai N, Kaur R, Tyagi RD, Surampalli RY (2019) Oleaginous yeast biomass flocculation using bioflocculant produced in wastewater sludge and transesterification using petroleum diesel as a co-solvent. Renew Energy 131:217-228. https://doi.org/10.1016/j.renene.2018.06.066

Yin YJ, Tian ZM, Tang W, Li L, Song LY, Mcelmurry SP (2014) Production and characterization of high efficiency bioflocculant isolated from Klebsiella sp. ZZ-3. Bioresour Technol 171:336-342. https://doi.org/10.1016/j.biort ech.2014.08.094

Yu L, Tang QW, Zhang YJ, Chen RP, Liu X, Qiao WC, Li WW, Ruan HH, Song X (2016) A novel Fe (III) dependent bioflocculant from Klebsiella oxytoca GS-4-08: culture conditions optimization and flocculation mechanism. Sci Rep 6(1):1-11. https://doi.org/10.1038/srep34980

Yu L, Hua JQ, Fan HC, George O, Lu Y (2020a) Simultaneous nitriles degradation and bioflocculant production by immobilized $K$. oxytoca strain in a continuous flow reactor. J Hazard Mater 387:121697. https://doi.org/10. 1016/j.jhazmat.2019.121697

Yu X, Wei X, Chi Z, Liu GL, Hu Z, Chi ZM (2020b) Improved production of an acidic exopolysaccharide, the efficient flocculant, by Lipomyces starkeyi U9 overexpressing UDP-glucose dehydrogenase gene. Int J Biol Macromol 165:1656-1663. https://doi.org/10.1016/j.ijbiomac.2020.10.090

Zaki S, Etarahony M, Elkady M, Abd-El-Haleem D (2014) The use of bioflocculant and bioflocculant-producing Bacillus mojavensis strain 32A to synthesize silver nanoparticles. J Nanomater 2014:431089. https://doi. org/10.1155/2014/431089

Zhang YX, Perry K, Vinci VA, Powell K, Stemmer WP, del Cardayré SB (2002) Genome shuffling leads to rapid phenotypic improvement in bacteria. Nature 415(6872):644-646. https://doi.org/10.1038/415644a

Zhang X, Sun J, Liu X, Zhou J (2013) Production and flocculating performance of sludge bioflocculant from biological sludge. Bioresour Technol 146:51-56. https://doi.org/10.1016/j.biortech.2013.07.036

Zhang C, Wang X, Wang Y, Li Y, Zhou D, Jia Y (2016) Synergistic effect and mechanisms of compound bioflocculant and $\mathrm{AICl}_{3}$ salts on enhancing Chlorella regularis harvesting. Appl Microbiol Biotechnol 100(12):56535660. https://doi.org/10.1007/s00253-016-7543-3

Zhang SS, Xu JF, Sun XL, Guo W, Liu ZS (2021) Cellulomonas taurus sp. Nov., a novel bacteria with multiple hydrolase activity isolated from livestock, and potential application in wastewater treatment. Antonie Van Leeuwenhoek 114(5):527-538. https://doi.org/10.1007/s10482-021-01538-2

Zhao Y, Gao B, Shon H, Wang Y, Kim JH, Yue Q, Bo X (2012) Anionic polymer compound bioflocculant as a coagulant aid with aluminum sulfate and titanium tetrachloride. Bioresour Technol 108:45-54. https://doi.org/10. 1016/j.biortech.2012.01.012

Zhao H, Liu H, Zhou J (2013) Characterization of a bioflocculant MBF-5 by Klebsiella pneumoniae and its application in Acanthamoeba cysts removal. Bioresour Technol 137:226-232. https://doi.org/10.1016/j.biortech.2013. 03.079

Zhao C, Zhao X, Gu H, Zhang J, Zou W, Liu J, Yang Q (2016) Qualitative analysis of components of bioflocculant prepared with Bacillus fusiformis for the treatment of tannery wastewater. Clean Technol Environ 18(3):973-978. https://doi.org/10.1007/s10098-015-1085-8

Zhao H, Cao G, Chen H, Li H, Zhou J (2017) Evaluation of hemocompatibility and hemostasis of a bioflocculant. Colloids Surf B Biointerfaces 159:712-719. https://doi.org/10.1016/j.colsurfb.2017.08.054

Zhao H, Zheng Y, Zhou S, Liu L, Zhou J, Sun S (2020) Characteristics of methane and bioflocculant production by Methanosarcina spelaei RK-23. Int J Hydrog Energy 45(20):11569-11576. https://doi.org/10.1016/j.ijhydene. 2020.02 .088

Zhong C, Xu A, Chen L, Yang X, Yang B, Hong W, Mao K, Wang B, Zhou J (2014) Production of a bioflocculant from chromotropic acid waste water and its application in steroid estrogen removal. Colloids Surf B Biointerfaces 122:729-737. https://doi.org/10.1016/j.colsurfb.2014.08.006

Zhong CY, Chen HG, Cao G, Wang J, Zhou JG (2016) Bioflocculant production by Haloplanus vescus and its application in acid brilliant scarlet yellow/ 
red removal. Water Sci Technol 73(4):707-715. https://doi.org/10.2166/ wst.2015.549

Zhong C, Cao G, Rong K, Xia Z, Peng T, Chen H, Zhou J (2018) Characterization of a microbial polysaccharide-based bioflocculant and its antiinflammatory and pro-coagulant activity. Colloids Surf B Biointerfaces 161:636-644. https://doi.org/10.1016/j.colsurfb.2017.11.042

Zhong C, Sun S, Zhang D, Liu L, Zhou S, Zhou J (2020) Production of a bioflocculant from ramie biodegumming wastewater using a biomassdegrading strain and its application in the treatment of pulping wastewater. Chemosphere 253:126727. https://doi.org/10.1016/j. chemosphere.2020.126727
Zhu C, Chen C, Zhao L, Zhang Y, Yang J, Song L, Yang S (2012) Bioflocculant produced by Chlamydomonas reinhardtii. J Appl Phycol 24(5):12451251. https://doi.org/10.1007/s10811-011-9769-x

Zou X, Li Y, Xu K, Wen H, Shen Z, Ren X (2018) Microalgae harvesting by buoybead flotation process using bioflocculant as alternative to chemical flocculant. Algal Res 32:233-240. https://doi.org/10.1016/j.algal.2018. 04.010

\section{Publisher's Note}

Springer Nature remains neutral with regard to jurisdictional claims in published maps and institutional affiliations.

\section{Submit your manuscript to a SpringerOpen ${ }^{\circ}$ journal and benefit from:}

- Convenient online submission

- Rigorous peer review

- Open access: articles freely available online

- High visibility within the field

- Retaining the copyright to your article

Submit your next manuscript at $\gg$ springeropen.com 